San Jose State University

SJSU ScholarWorks

Master's Theses

Master's Theses and Graduate Research

1995

\title{
Identification of a sporulation gene in Bacillus thuringiensis using transposon-mediated insertional mutagenesis
}

Mitra Shahabi Reynoso

San Jose State University

Follow this and additional works at: https://scholarworks.sjsu.edu/etd_theses

\section{Recommended Citation}

Reynoso, Mitra Shahabi, "Identification of a sporulation gene in Bacillus thuringiensis using transposonmediated insertional mutagenesis" (1995). Master's Theses. 1027.

DOI: https://doi.org/10.31979/etd.bj2g-2qq4

https://scholarworks.sjsu.edu/etd_theses/1027

This Thesis is brought to you for free and open access by the Master's Theses and Graduate Research at SJSU ScholarWorks. It has been accepted for inclusion in Master's Theses by an authorized administrator of SJSU ScholarWorks. For more information, please contact scholarworks@sjsu.edu. 


\section{INFORMATION TO USERS}

This manuscript has been reproduced from the microfilm master. UMI films the text directly from the original or copy submitted. Thus, some thesis and dissertation copies are in typewriter face, while others may be from any type of computer printer.

The quality of this reproduction is dependent upon the quality of the copy submitted. Broken or indistinct print, colored or poor quality illustrations and photographs, print bleedthrough, substandard margins, and improper alignment can adversely affect reproduction.

In the unlikely event that the author did not send UMI a complete manuscript and there are missing pages, these will be noted. Also, if unauthorized copyright material had to be removed, a note will indicate the deletion.

Oversize materials (e.g., maps, drawings, charts) are reproduced by sectioning the original, beginning at the upper left-hand corner and contimuing from left to right in equal sections with small overlaps. Each original is also photographed in one exposure and is included in reduced form at the back of the book

Photographs included in the original manuscript have been reproduced xerographically in this copy. Higher quality $6^{n} \times 9^{n}$ black and white photographic prints are available for any photographs or illustrations appearing in this copy for an additional charge. Contact UMI directly to order.

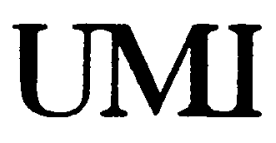

A Bell \& Howell Information Company 300 North Zeeb Road. Ann Arbor. Ml 48106-1346 USA $313: 761-4700 \quad 800: 521-0600$ 
IDENTIFICATION OF A SPORULATION GENE IN BACILLUS

\title{
THURINGIENSIS USING TRANSPOSON-MEDIATED INSERTIONAL MUTAGENESIS
}

\author{
A Thesis \\ Presented to \\ the Faculty of the Department of Biological Scjences \\ San Jose State University
}

\author{
In Partial Fulfillment \\ of the Requirements of the Degree \\ Master of Science
}

by

Mitra Shahabi Reynoso

May, 1995 
UMI Number: 1374618

UMI Microform 1374618

Copyright 1995, by UMI Company. All rights reserved.

This microform edition is protected against unauthorized copying under Title 17, United States Code.

\section{UMI}

300 North Zeeb Road

Ann Arbor, MI 48103 
(C) 1995

Mitra Shahabi Reynoso

ALL RIGHTS RESERVED 
APPROVED FOR THE DEPARTMENT OF BIOLOGICAL SCIENCES
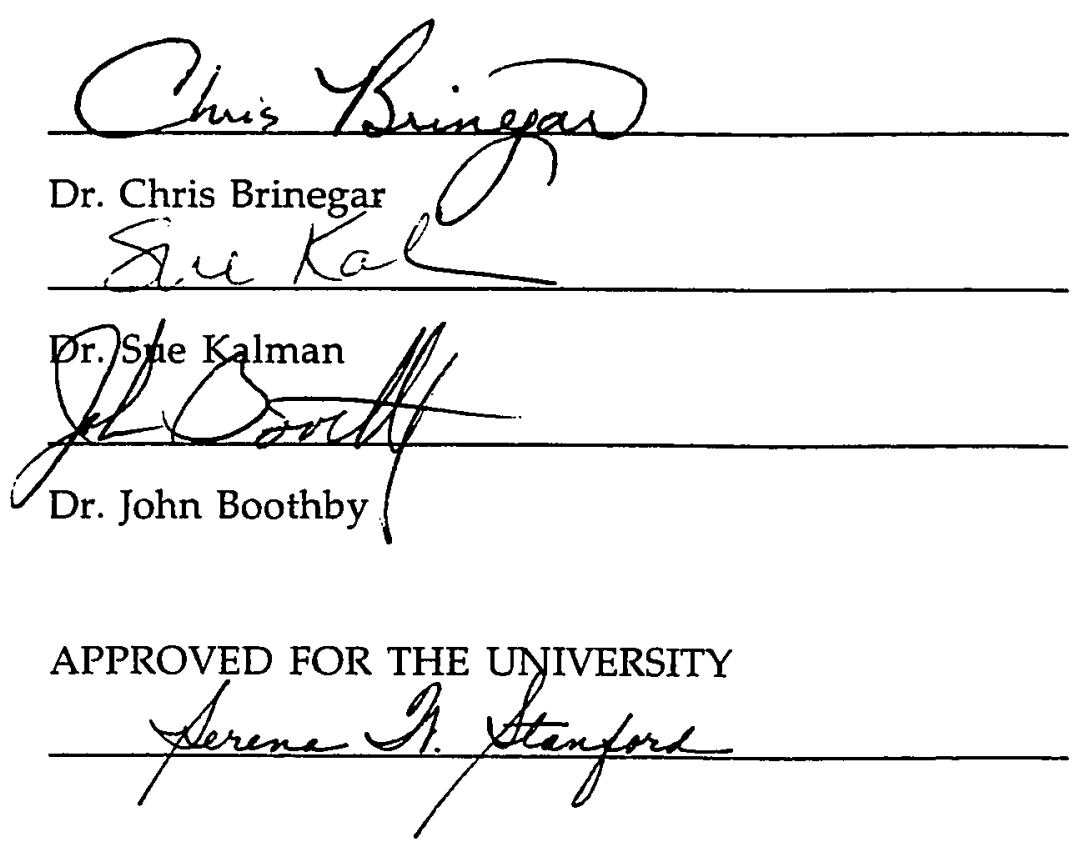


\begin{abstract}
IDENTIFICATION OF A SPORULATION GENE IN BACILLUS THURINGIENSIS USING TRANSPOSON-MEDIATED INSERTIONAL MUTAGENESIS
\end{abstract}

by Mitra Shahabi Reynoso

Bacillus thuringiensis has been used extensively as a biological insecticide to control a wide range of insect pests. Under conditions of nutrient limitation, this organism undergoes sporulation which is a unicellular differentiation process. Numerous genes responsible for different stages of spore formation have been characterized in Bacillus species. However, only a few sporulation genes have been identified in Bacillus thuringiensis.

Using transposon Tn917 insertional mutagenesis, a new sporulation gene was identified in Bacillus thuringiensis. Approximately $70 \%$ identity at both the DNA and the protein level was observed between the isolated sporulation gene and the spoVJ gene from Bacillus subtilis. The spoVJ mutant of Bacillus thuringiensis produced immature spores that were sensitive to heat and organic solvents but resistant to lysozyme. These phenomena were also observed in the Bacillus subtilis spoVJ mutant. Based on these results, it is concluded that the isolated gene is indeed the spoVJ gene from Bacillus thuringiensis. 


\section{ACKNOWLEDGEMENT}

Special thanks are due to Dr. Sue Kalman for her endless patience, guidance, and support during my thesis project, to thesis committee members Dr. Chris Brinegar and Dr. John Boothby for their contributions, to Nicole Sinibaldi for helping me during moments of crisis and being so patient, to Gary Powell for providing computer support when I needed it, to Dave Matthews for preparing the oligonucleotides needed for sequencing, and to Sandoz Agro Inc. for allowing me to conduct my research in their facilities.

Finally, I would like to acknowledge the support I received from my husband, Sam, who helped make my thesis-related stress a little more bearable, and from my parents who taught me the value of a good education. 


\section{TABLE OF CONTENTS}

Page

ABSTRACT ........................ iv

ACKNOWLEDGEMENT ........................ v

TABLE OF CONTENTS . . . . . . . . . . . . . . . . . vi

LIST OF TABLES. ........................ viii

LIST OF FIGURES $\ldots \ldots \ldots \ldots \ldots \ldots \ldots \ldots \ldots \ldots \ldots \ldots \ldots \ldots \ldots \ldots$

INTRODUCTION ......................... 1

LITERATURE REVIEW . . . . . . . . . . . . . . . . 3

MATERIALS AND METHODS.$\ldots \ldots \ldots \ldots \ldots \ldots \ldots \ldots \ldots$

Bacterial Strains. .................... 8

Media, Materials, and Bacterial Growth........... 8

Isolation of DNA from Bacillus and E. coli Strains.......... 10

B. subtilis plasmid preparation. . . . . . . . . . 10

B. thuringiensis plasmid DNA isolation......... 12

Total DNA isolation from $B$. thuringiensis. . . . . . . 12

E. coli plasmid DNA preparation.............. 13

DNA Methods......................... 14

Polymerase chain reaction $\ldots \ldots \ldots \ldots \ldots \ldots \ldots \ldots$

Agarose gel electrophoresis............... 15

DNA sequencing $\ldots \ldots \ldots \ldots \ldots \ldots \ldots \ldots \ldots \ldots \ldots \ldots \ldots \ldots$

Preparation of Competent Cells................... 16

B. thuringiensis competent cells............. 16

High efficiency E. coli GM2163 electro-competent cells... . 16

E. coli DH5 $\alpha$ and HB101 competent cells........... 17 


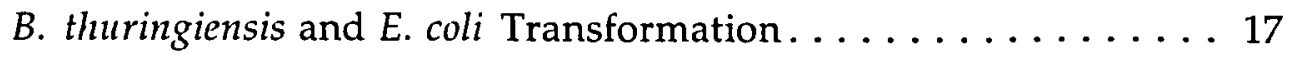

Electroporation of B. thuringiensis. . . . . . . . . 17

Electroporation of E. coli strain GM2163.......... 18

Transformation of E. coli strains DH5 $\alpha$ and HB101.... . 18

Determination of pLTV1 Stability in B. thuringiensis........ 19

Preparation of Tn917 Insertion Libraries. . . . . . . . . . . 19

Transduction........................ 20

Preparation of phage lysate. . . . . . . . . . 20

Generalized transduction................. 21

Cloning the Chromosomal DNA Adjacent to Transposon

Insertions . . . . . . . . . . . . . . . . 21

Characterization of Mutant Spores............... 22

RESULTS............................ 24

Characterization of $B$. thuringiensis HD1Mit9.......... 24

Transformation of B. thuringiensis with Plasmid pLTV1..... 25

Stability of pLTV1 in HD1Mit9. . . . . . . . . . . . 32

Isolation and Characterization of HD1Mit9 Sporulation Mutants. 34

Verification that $\operatorname{Tn} 917$ Inserted into a Sporulation Gene. . . . . . 37

Isolation and DNA Sequence of the Chromosomal DNA

Flanking the Tn917 Insertions. . . . . . . . . . . . 38

Growth Rate of HD1Mit9 and HD1Mit9::Tn917 \#1 . . . . . . 56

Characterization of the Mutant Spores............. 58

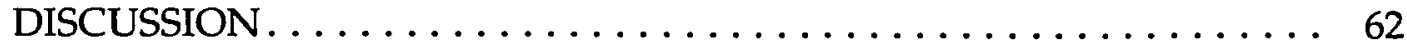

LITERATURE CITED $\ldots \ldots \ldots \ldots \ldots \ldots \ldots \ldots \ldots \ldots \ldots \ldots \ldots \ldots \ldots \ldots \ldots$ 


\section{LIST OF TABLES}

Table Page

1. Oligonucleotide primers used for the detection of pLTV1 in $B$. thuringiensis............................ 30

2. The percentage of HD1Mit9 cells containing plasmid pLTV1 at various temperatures $\ldots \ldots \ldots \ldots \ldots \ldots \ldots \ldots \ldots \ldots \ldots \ldots$

3. Primers used for sequencing the B. thuringiensis spoVJ gene. . . . . 47

4. Comparison between the B. subtilis spoVI gene and the cloned sporulation gene from B. thuringiensis HD1Mit9::Tn917 \#1 . . . . . . 49

5. Resistance properties of HD1Mit9::Tn917 \#1 (mutant) and $B$. thuringiensis HD1Mit9 (wild type) spores to heat, lysozyme, and organic solvents........................ 60 


\section{LIST OF FIGURES}

Figure Page

1. Map of plasmid pLTV1 $\ldots \ldots \ldots \ldots \ldots \ldots \ldots \ldots \ldots \ldots \ldots \ldots \ldots \ldots \ldots$

2. Agarose gel electrophoresis of plasmid pLTV1 digested with EcoRI. . . . . . . . . . . . . . . . . . . . . . . . . 29

3. Agarose gel analysis of PCR performed to confirm the presence of pLTV1 in B. thuringiensis HD1Mit9 and Cry-B . . . . . . . . . 31

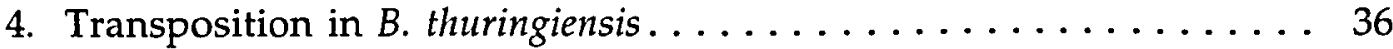

5. Cloning strategy used to isolate the HD1Mit9::Tn917 \#1 sporulation gene interrupted by $\operatorname{Tn} 917 \ldots \ldots \ldots \ldots \ldots \ldots \ldots \ldots$

6. Map of plasmid $p S B 1211 \ldots \ldots \ldots \ldots \ldots \ldots \ldots \ldots \ldots \ldots \ldots$

7. Map of plasmid pSB1212 . . . . . . . . . . . . . . . . 42

8. Map of plasmid $p S B 1213 \ldots \ldots \ldots \ldots \ldots \ldots \ldots \ldots \ldots \ldots \ldots \ldots$

9. Restriction enzyme digests of plasmid pSB1211 . . . . . . . . . . 44

10. Restriction enzyme digests of plasmid pSB1212 . . . . . . . . . 45

11. Restriction enzyme digests of plasmid pSB1213 . . . . . . . . 46

12. (A) Location of oligonucleotides used for sequencing the $B$. thuringiensis sporulation gene (spo gene); (B) list of the primers used for sequencing. . . . . . . . . . . . . . . 48

13. Sequence of the $B$. thuringiensis HD1Mit9 spoVJ gene. . . . . . . . 51

14. Amino acid comparison between the SpoVJ proteins from $B$. subtilis and $B$. thuringiensis HD1Mit9 . . . . . . . . . 55

15. Growth curves of HD1Mit9 and HD1Mit9::Tn917\#1 . . . . . . . 57

16. Spores from B. thuringiensisHD1Mit9 (a) and HD1Mit9::Tn917

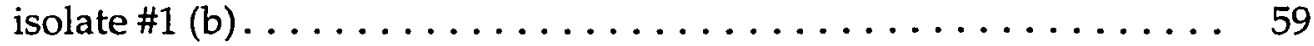


17. Resistance properties of spores from HD1Mit9 and HD1Mit9::Tn917 \#1 to heat, lysozyme, and organic solvents . . . . . 61 


\section{INTRODUCTION}

Sporulation, a survival mechanism available to some bacteria in response to extreme environmental conditions, involves a radical change of the biosynthetic activities in the bacterium. The genes that are needed for sporulation can be recognized by creating mutations which permit normal vegetative growth, but block sporulation. Sandman et al. (1987) performed a genetic analysis of Bacillus subtilis sporulation mutants produced by transposon-mediated insertional mutagenesis. The transposon used was the Streptococcus faecalis transposon Tn917. In Sandman's study, the insertion mutations blocked sporulation at various stages and therefore identified genes active at different times during sporulation.

Bacillus thuringiensis, which has some of the same phenotypic properties as $B$. subtilis, produces crystalline protein bodies in addition to endospores during sporulation. The crystals from different strains of $B$. thuringiensis are toxic to several orders of insects, such as larvae of Lepidoptera and Coleoptera. B. thuringiensis has been of great interest to many researchers due to its importance in the biological control of these agricultural pests. Although many studies have been done on the crystal proteins from $B$. thuringiensis, little is known about the sporulation genes. These genes are not only associated with crystal production but are also responsible for sporulation, a process used by this organism to survive under certain conditions of nutrient limitation.

In the current study, the transposon-mediated insertional mutagenesis technique was used to identify genes involved in spore formation in $B$. 
thuringiensis subspecies kurstaki HD1Mit9. A sporulation mutant was created using transposon Tn917. The gene interrupted with Tn917 was isolated, cloned into an Escherichia coli strain, sequenced, and compared to the known sporulation genes in B. subtilis using computer analysis. 


\section{LITERATURE REVIEW}

B. thuringiensis is a gram-positive, aerobic, spore-forming bacterium that can produce crystalline inclusions during sporulation. The inclusions are composed of one or more insecticidal proteins which are toxic to certain insect larvae (Cooper, 1994). Insecticidal proteins toxic to lepidopteran, coleopteran, and dipteran insect larvae have been characterized (Whiteley and Schnepf, 1986). Over the past few decades, B. thuringiensis-based products have been widely used for the control of agricultural and forest pests. One important advantage of using biological insecticides is that they have the ability to destroy pests resistant to chemicals (Watkinson, 1994). Many countries, including Australia and the USA, use B. thuringiensis-based products for the control of diamondback moth resistant to pyrethroids.

B. thuringiensis was first isolated by the Japanese bacteriologist $\mathrm{S}$. Ishiwata in 1901 from a diseased silkworm larvae (Beegle and Yamamoto, 1992). Because the isolated Bacillus strain was extremely pathogenic to larval silkworm, he named it Sottokin which means "sudden death bacillus". In 1915, Berliner isolated a similar Bacillus from a diseased Mediterranean flour moth from Thuringia, Germany, and named it B. thuringiensis (Beegle and Yamamoto, 1992). Studies done by Aoki and Chigasaki suggested that the toxicity of this organism was due to the presence of a protein found in sporulated cultures.

In 1951, Edward Steinhaus at the University of California at Berkeley,

published an article encouraging the commercial use of $B$. thuringiensis as a biological control agent for lepidopteran insect pests (Beegle and Yamamoto, 
1992). Since his work in the early 1950 's, various B. thuringiensis products have been used in most countries of the world for control of caterpillars, mosquitoes, blackfly, and beetle larvae (Milner, 1994).

Bacillus species undergo dramatic morphological, physiological, and biochemical changes during sporulation (Errington, 1993). These changes have been studied in great detail in B. subtilis. In general, sporulation is used as a terminal differentiation pathway for the organism under certain nutrient-limiting conditions. Once sporulation is initiated, the cells undergo seven morphological stages (Losick et al., 1986). Vegetative cells are said to be in stage 0 . As sporulation begins, the chromosome condenses into an axial filament. This event has been defined as stage I, but was disputed until recently because the event is not specific to sporulation and no mutations had been found in B. subtilis which block sporulation at this stage (Piggot and Coote, 1976). However, Tao and Vary (1991) have recently characterized a Bacillus megaterium sporulation mutant defective in stage I of development. At stage II, cell division occurs producing two cells that are different in size. The smaller cell is the daughter cell also known as forespore or prespore, and the larger cell is designated the mother cell. During stage III, the mother cell engulfs the forespore resulting in the formation of a double membrane around the forespore inside the mother cell. A modified form of a cell wall known as cortex is synthesized between the inner and outer membranes of the prespore during stage IV. Spore coat deposition on the outer membrane of the prespore occurs during stage V. Stage VI is defined as the complete maturation of the spore. At this stage the spore develops its characteristic properties of resistance to radiation, heat, lysozyme, and organic solvents. 
Finally, the mother cell lyses and the mature spore is released in stage VII. The free spore is refractile and can be easily observed using light microscopy.

Because of the considerable interest in the use of $B$. thuringiensis as a biological pesticide, numerous studies had been done to identify insecticidal proteins in this bacterium. However, little is known about the genes involved in the sporulation pathway of this organism. Most insecticidal crystal proteins are expressed only during sporulation (Beegle and Yamamoto, 1992). Because of this, it is also important to identify and characterize the genes involved in the sporulation pathway so that crystal production and sporulation can be manipulated.

One useful approach to identifying sporulation-associated genes is transposon-mediated insertional mutagenesis (Youngman, 1987). A transposon is a mobile segment of DNA that is flanked by terminal repeat sequences (Grindley and Reed, 1985). It is able to insert itself at a new site in the bacterial chromosome or plasmid, a process called transposition. Transposons also encode the proteins necessary for their transposition and some also carry an antibiotic resistance gene. If the insertion occurs within a gene, the protein encoded by that gene would most likely become nonfunctional.

In the current study, a sporulation gene was isolated from a $B$. thuringiensis strain using insertional mutagenesis with the $S$. faecalis transposon Tn917 (Tomich et al., 1980). Malvar and Baum (1994) used the same approach with a different transposon, $\operatorname{Tn} 5401$, to isolate the $B$. thuringiensis spo0F gene. In 1990, Crawford and Streips described a procedure to isolate $B$. thuringiensis sporulation mutants through Tn917 insertional 
mutagenesis. However, they did not report the characterization of any particular sporulation genes.

Tn917 had been used extensively in mutagenesis studies for $B$. megaterium and B. subtilis. Bohall and Vary (1986) obtained sixty-nine auxotrophs and forty-three sporulation mutants from B. megaterium using Tn917 insertional mutagenesis. They identified eight auxotrophic and two carbon source loci. However, the exact location of the sporulation mutations was not determined. In 1991, Tao and Vary characterized four B. megaterium insertion mutants defective in stages I and II of sporulation. Sandman et al. (1987) described the genetic and phenotypic characterization of twenty-four Tn917 insertional mutations in B. subtilis that blocked sporulation at different stages including 0, II, III, IV, and V. Vandeyar and Zahler (1986) isolated and mapped twenty-seven auxotrophic and nineteen cryptic insertions of Tn917 in the B. subtilis chromosome. In 1983, Youngman et al. recovered different kinds of auxotrophic and sporulation-defective B. subtilis mutants from a Tn917 insertion library. Approximately 1-2\% were auxotrophs and $0.1-0.5 \%$ were sporulation mutants. Youngman found three sporulation mutants that blocked development at stage II or III of the sporulation pathway, based on their phenotypic characteristics. Tn917 was also used to identify genes involved in pathogenicity of Listeria monocytogenes (Camilli et al., 1990).

According to Youngman et al. (1983), the transposition frequency of Tn917 in B. subtilis was equivalent to that in Streptococcus species. It was also shown that the distribution of Tn917 insertions in the B. subtilis chromosome was sufficiently random. As a result, transposon Tn917 was 
chosen for isolation of a $B$. thuringiensis sporulation gene through mutagenesis.

In the current study, B. thuringiensis strain HD1Mit9 was used for isolation of a sporulation gene. This strain does not produce insecticidal proteins. HD1Mit9 was chosen because it contains only one plasmid and it is a derivative of $B$. thuringiensis subspecies kurstaki HD1, the most wellstudied B. thuringiensis strain. HD1 was isolated from diseased Pectinophora gossypiella larvae by Dulmage (1970). Later, HD1 was found to belong to a new subspecies of $B$. thuringiensis, which was named kurstaki (de Barjac and Lemille, 1970). 


\section{MATERIALS AND METHODS}

\section{Bacterial Strains}

The $B$. thuringiensis HD1Mit9 strain was obtained from Dr. Arthur I. Aronson (Purdue University). Cry-B, a crystal-minus cured strain of $B$. thuringiensis, was received from Repligen Sandoz Research Corporation (Lexington, MA). Plasmid pLTV1, which contains transposon Tn917, was isolated from the B. subtilis strain PY1177 obtained from Dr. Philip Youngman (University of Pennsylvania School of Medicine). The E. coli strains DH5 $\alpha$ [F- $\phi 80 \mathrm{~d}$ lacZAM15 $\Delta$ (lacZYA-argF)U169 deoR recA1 endA1 $h s d \mathrm{R} 17\left(\mathrm{rk}_{\mathrm{k}}^{-}, \mathrm{mk}_{\mathrm{k}}\right)$ ) supE44 $\lambda^{-}$thi-1 gyrA96 relA1] from Gibco BRL (Grand Island, NY), GM2163 [F- ara-14 leuB6 ton A31 lac Y1 tsx-78 supE44 galK2 galT22

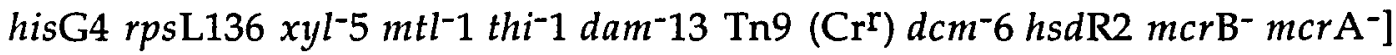
from New England Biolabs, Inc. (Beverly, MA), and HB101 [F $\mathrm{F}^{-} \mathrm{mcrB}$ mrr hsdS20 $\left(\mathrm{rb}^{-} \mathrm{mb}^{-}\right)$recA13 sup E44 ara14 galK2 lac $\mathrm{Y} 1$ proA2 $\operatorname{rpsL20}\left(\mathrm{Sm}^{\mathrm{r}}\right) x y l 5^{-} \lambda^{-}$ leu mtl1] from New England Biolabs, Inc. were used as hosts for plasmid DNA in this study.

\section{Media, Materials, and Bacterial Growth}

Phage CP-51ts 45 used for transduction was obtained from Dr. Curtis B. Thorne (University of Massachusetts at Amherst). The restriction enzymes, T4 DNA Ligase, and reaction buffers were purchased from New England Biolabs, Inc., Pharmacia Biotechnology (Piscataway, NJ), or Gibco BRL. The antibiotics such as ampicillin (Amp), chloramphenicol (Cm), erythromycin (Ery), lincomycin (Lm), tetracycline (Tet), and chemicals were obtained from 
Sigma Chemical Company (St. Louis, MO). The oligonucleotides used for the polymerase chain reaction (PCR) and sequencing were synthesized on a PCRMate DNA synthesizer model 391 (Applied Biosystems, Foster City, CA) by Dave Matthews at Sandoz Agro, Inc. (Palo Alto, CA).

The E. coli and B. thuringiensis strains were grown in L-broth (LB) medium ( $1 \%$ Bacto Tryptone, $0.5 \%$ Bacto Yeast Extract, $0.5 \% \mathrm{NaCl}, \mathrm{pH} 7.0$ ) at $37^{\circ} \mathrm{C}$ and $30^{\circ} \mathrm{C}$ respectively, unless otherwise stated. Solid media were prepared using $15 \mathrm{~g}$ Bacto agar per liter. High efficiency E. coli competent cells used for electroporation were made using SOB medium (2\% Bacto Tryptone, $0.5 \%$ Bacto Yeast Extract, $0.06 \% \mathrm{NaCl}, 0.05 \% \mathrm{KCl}, 10 \mathrm{mM} \mathrm{MgCl} 2,10 \mathrm{mM}$ $\left.\mathrm{MgSO}_{4}\right)$. After electroporation, E. coli cells were grown in SOC medium (2\% Bacto Tryptone, $0.5 \%$ Bacto Yeast Extract, $0.06 \% \mathrm{NaCl}, 0.05 \% \mathrm{KCl}, 20 \mathrm{mM}$ glucose). SA plates ( $1 \times$ Spizizens salts, $1 \%$ casamino acids, $0.5 \%$ glucose, 0.005 $\mathrm{mM} \mathrm{MnSO}_{4} . \mathrm{H}_{2} \mathrm{O}, 1.5 \%$ Bacto agar) were used for $B$. thuringiensis plasmid isolation. The $1 \times$ Spizizens salts were made of $0.2 \%\left(\mathrm{NH}_{4}\right)_{2} \mathrm{SO}_{4}, 1.4 \%$ $\mathrm{K}_{2} \mathrm{HPO}_{4}, 0.6 \% \mathrm{KH}_{2} \mathrm{PO}_{4}, 0.1 \%$ Sodium-Citrate $2 \mathrm{H}_{2} \mathrm{O}$, and $0.02 \% \mathrm{MgSO}_{4} \cdot 7 \mathrm{H}_{2} \mathrm{O}$ (Anagnostopoulos and Spizizen, 1961). BHIS medium (3.7\% Brain Heart Infusion, $0.5 \mathrm{M}$ sucrose) was used for preparation of $B$. thuringiensis competent cells. Penassay broth (1.75\% Difco Antibiotic Medium 3) was used for preparation of $\operatorname{Tn} 917$ insertion libraries. B. thuringiensis colonies with transposon insertions were grown on CYS plates ( $1 \%$ Casitone, $0.5 \%$ glucose, $0.2 \%$ Bacto Yeast Extract, $0.1 \% \mathrm{KH}_{2} \mathrm{PO}_{4}, 0.5 \mathrm{mM} \mathrm{MgCl} 2,0.05 \mathrm{mM} \mathrm{Mr} \mathrm{Cl}_{2}, 0.05$ $\mathrm{mM} \mathrm{ZnSO} 4,0.05 \mathrm{mM} \mathrm{FeCl}_{2}, 0.2 \mathrm{mM} \mathrm{CaCl} 2,1.5 \%$ Bacto agar) to test their ability to sporulate. Phage Assay (PA) medium ( $0.8 \%$ nutrient broth, $0.5 \%$ 
$\left.\mathrm{NaCl}, 0.02 \% \mathrm{MgSO}_{4} \cdot 7 \mathrm{H}_{2} \mathrm{O}, 0.005 \% \mathrm{MnSO}_{4} \cdot \mathrm{H}_{2} \mathrm{O}, 0.015 \% \mathrm{CaCl}_{2} \cdot 2 \mathrm{H}_{2} \mathrm{O}, \mathrm{pH} 6.0\right)$ was used for preparation of phage lysates in transduction experiments.

To identify auxotrophs and citric acid cycle-defective colonies, the $B$. thuringiensis sporulation mutants were grown on glucose minimal and lactate minimal plates for 1-2 days, and the growth was compared to that of HD1Mit9. The glucose minimal agar was made of $1 \mathrm{x}$ salt solution [1 liter; $5.6 \mathrm{~g}$ $\mathrm{K}_{2} \mathrm{HPO}_{4}, 2.4 \mathrm{~g} \mathrm{KH}_{2} \mathrm{PO}_{4}, 1.2 \mathrm{~g}\left(\mathrm{NH}_{4}\right)_{2} \mathrm{SO}_{4}, 0.4 \mathrm{~g}$ sodium citrate, $\left.\mathrm{pH} 7.0\right], 0.005$ $\mathrm{mM} \mathrm{FeCl} 2,0.25 \mathrm{mM} \mathrm{MgCl} 2,0.96 \%$ glucose, $0.0002 \mathrm{mM} \mathrm{MnCl} 2,0.00012 \%$ Thiamine-B1, and 1.5\% Bacto agar. The lactate minimal medium contained $0.2 \%$ lactate and $25 \mathrm{mM}$ glutamate instead of glucose and sodium citrate.

The expression of the lac $Z$ gene in transposon $\mathrm{Tn} 917$ was examined by growing the strains carrying the transposon on LB agar plates containing Ery 5 (erythromycin at $5 \mu \mathrm{g} / \mathrm{ml}$ ) and $60 \mu \mathrm{g} / \mathrm{ml}$ of 5-bromo-4-chloro-3-indolyl-ß-Dgalactoside (X-Gal) for five days, and observing the colonies for the presence or absence of blue color. To determine the growth rates of the $B$. thuringiensis strains, cells were grown overnight on CYS plates and single colonies were used to inoculate $100 \mathrm{ml}$ of CYS medium in a $500 \mathrm{ml}$ flask. The cultures were incubated at $30^{\circ} \mathrm{C}$ and 300 revolutions per minute (rpm). The growth was monitored by optical density at $600 \mathrm{~nm}\left(\mathrm{OD}_{600}\right)$ every half hour until the transition from exponential growth into stationary phase occurred.

\section{Isolation of DNA from Bacillus and E. coli Strains}

B. subtilis plasmid preparation. The strain was grown overnight (18-20 hours) on TBAB plates (3.3\% Difco Tryptose Blood Agar Base) containing $0.5 \%$ glucose and $\mathrm{Tet}^{10}$. A single colony was used to inoculate $10 \mathrm{ml} \mathrm{LB}$ 
containing $\mathrm{Tet}^{10}$ and $0.5 \%$ glucose. The cells were grown for 5 hours at 300 $\mathrm{rpm}$, centrifuged at $18,500 \times \mathrm{g}$ and $4^{\circ} \mathrm{C}$ for 10 minutes, then washed once in 10 $\mathrm{ml}$ of SET buffer [ $20 \%$ sucrose, $50 \mathrm{mM}$ disodium ethylenediaminetetraacetate $2 \mathrm{H}_{2} \mathrm{O}$ (EDTA), $50 \mathrm{mM}$ Tris- $\mathrm{HCl} \mathrm{pH}$ 8.0]. The pellet was then resuspended in $500 \mu \mathrm{l} \mathrm{SET} \mathrm{solution} \mathrm{containing} 2 \mathrm{mg} / \mathrm{ml}$ of lysozyme and 0.4 $\mathrm{mg} / \mathrm{ml}$ RNase A (Boehringer Mannheim Biochemicals, Indianapolis, IN). The cell suspension was incubated at $37^{\circ} \mathrm{C}$ for 10 minutes and $1 \mathrm{ml}$ of the lytic mix [1\% sodium dodecycl sulfate (SDS), $200 \mathrm{mM} \mathrm{NaOH}$ ] was added, followed by $725 \mu$ l of prechilled neutralization buffer (1.5 M potassium acetate $\mathrm{pH} 4.8)$. The mixture was then incubated on ice for $\mathbf{2 0}$ minutes. The sample was microcentrifuged at $18,500 \times \mathrm{g}$ and $4^{\circ} \mathrm{C}$ for 10 minutes and the supernatant was transferred to a fresh tube. The DNA was then isolated using a Mini Qiagen Plasmid Kit (Qiagen Inc., Chatsworth, CA) as follows. A Qiagen-Tip 20 column was equilibrated with $1 \mathrm{ml}$ QBT equilibration buffer $[750 \mathrm{mM} \mathrm{NaCl}$, $50 \mathrm{mM}$ 3-(N-morpholino)propanesulfonic acid (MOPS) $\mathrm{pH}$ 7.0, 15\% ethanol, $0.15 \%$ Triton $X-100]$. The supernatant was applied to the column and allowed to enter the resin by gravity flow. The Qiagen column was washed with $2 \mathrm{ml}$ QC wash buffer (1.0 M NaCl, $50 \mathrm{mM}$ MOPS $\mathrm{pH} 7.0,15 \%$ ethanol), and the DNA was eluted using $0.8 \mathrm{ml}$ QF elution buffer $(1.25 \mathrm{M} \mathrm{NaCl}$, $50 \mathrm{mM}$ Tris$\mathrm{HCl} \mathrm{pH} \mathrm{8.5,} \mathrm{15 \%} \mathrm{ethanol).} \mathrm{The} \mathrm{DNA} \mathrm{was} \mathrm{precipitated} \mathrm{using} 500 \mu \mathrm{l}$ isopropanol and microcentrifuged at room temperature for 25 minutes at $16,000 \times \mathrm{g}$. The DNA pellet was washed in prechilled $70 \%$ ethanol and then resuspended in $20 \mu \mathrm{l} \mathrm{TE}$ (10 mM Tris- $\mathrm{HCl}$ pH 8.0, $1 \mathrm{mM}$ EDTA) or sterile deionized distilled water $\left(\mathrm{ddH}_{2} \mathrm{O}\right)$. For long term storage, the DNA was kept at $-20^{\circ} \mathrm{C}$. 
B. thuringiensis plasmid DNA isolation. HD1Mit9 and Cry-B were streaked onto LB agar plates, and HD1Mit9/pLTV1 and Cry-B/pLTV1 (the B. thuringiensis strains containing plasmid pLTV1) onto LB Tet ${ }^{10}$ plates. The cultures were grown overnight, and a single colony from each strain was restreaked onto an SA plate and incubated for 3-4 hours at $37^{\circ} \mathrm{C}$. The grown cells were removed from the plate and resuspended in $100 \mu \mathrm{l}$ TESL (100 mM Tris- $\mathrm{HCl} \mathrm{pH}$ 8.0, $10 \mathrm{mM}$ EDTA, 20\% sucrose, $2 \mathrm{mg} / \mathrm{ml}$ lysozyme), and incubated at $37^{\circ} \mathrm{C}$ for $30-60$ minutes. Two hundred microliters of lysis solution ( $200 \mathrm{mM} \mathrm{NaOH}, 1 \% \mathrm{SDS}$ ) were added to each tube followed by a 5 minute incubation at room temperature. After addition of $150 \mu \mathrm{l}$ ice-cold $3 \mathrm{M}$ potassium acetate $\mathrm{pH} 4.8$, the suspension was microcentrifuged for 20 minutes at $18,500 \times \mathrm{g}$ and $4^{\circ} \mathrm{C}$. The supernatants were transferred to fresh tubes and mixed with $1 \mathrm{ml}$ of $100 \%$ ethanol. This suspension was left at $-20^{\circ} \mathrm{C}$ for 1 hour and centrifuged at $18,500 \times \mathrm{g}$ and $4^{\circ} \mathrm{C}$ for 30 minutes. The plasmid DNA was washed in $70 \%$ ethanol, dried under vacuum, and resuspended in $20 \mu \mathrm{l}$ of TE.

Total DNA isolation from B. thuringiensis. The strain was grown in 2 $\mathrm{ml} \mathrm{LB}$ overnight at $200 \mathrm{rpm}$. The overnight culture was used to inoculate 100 $\mathrm{ml} \mathrm{LB} \mathrm{(1 \%} \mathrm{inoculation).} \mathrm{The} \mathrm{cells} \mathrm{were} \mathrm{grown} \mathrm{at} 300 \mathrm{rpm}$ to an $\mathrm{OD} 600$ of $0.7-$ 1.0 , collected by centrifugation $\left(3,840 \times \mathrm{g}, 5\right.$ minutes, $\left.4^{\circ} \mathrm{C}\right)$, and resuspended in $5 \mathrm{ml}$ TES (25 mM Tris- $\mathrm{HCl} \mathrm{pH} \mathrm{8.0,} 25 \mathrm{mM}$ EDTA, 25\% sucrose). The cell suspension was mixed with $0.55 \mathrm{ml}$ of $10 \mathrm{mg} / \mathrm{ml}$ lysozyme in TES solution and incubated at $37^{\circ} \mathrm{C}$ for 60 minutes. SDS was added to $2 \%$ weight-to- 
volume, followed by a 15 minute incubation at $50^{\circ} \mathrm{C}$. The suspension was then mixed with $1.52 \mathrm{ml}$ of $5 \mathrm{M} \mathrm{NaCl}$ and incubated at $50^{\circ} \mathrm{C}$ for 5 minutes. The sample was incubated at $0^{\circ} \mathrm{C}$ for 1 hour, centrifuged for 10 minutes at $18,500 \times \mathrm{g}$ and $4^{\circ} \mathrm{C}$, and the supernatant was transferred to a new tube. To purify the DNA from the protein, the supernatant was treated with phenol and chloroform. First, it was mixed with $5 \mathrm{ml} \mathrm{TE}$-equilibrated phenol followed by 15 minutes incubation at $50^{\circ} \mathrm{C}$, then with $5 \mathrm{ml}$ phenol/chloroform (1:1), and finally with $5 \mathrm{ml}$ chloroform. The aqueous phase was separated from the organic phase by centrifugation $(4,000 \times \mathrm{g}, 5$ minutes) at each step. The DNA was precipitated by the addition of $4.6 \mathrm{ml}$ isopropanol and centrifugation $\left(18,500 \times \mathrm{g}, 30\right.$ minutes, $\left.4^{\circ} \mathrm{C}\right)$. The air-dried DNA pellet was dissolved in $2 \mathrm{ml}$ of TE and stored at $-20^{\circ} \mathrm{C}$.

E. coli plasmid DNA preparation. The following protocol was used to isolate plasmid DNA for restriction enzyme digestion. The buffers (P1, P2, and P3) were obtained from Qiagen, Inc. The $E$. coli strain was grown in $4 \mathrm{ml}$ LB containing Amp 75 at 300 rpm for $18-20$ hours. The culture was centrifuged $\left(4,000 \times \mathrm{g}, 4^{\circ} \mathrm{C}, 10\right.$ minutes) and resuspended in $300 \mu \mathrm{l} 1$ (100 $\mu \mathrm{g} / \mathrm{ml}$ RNase A, $50 \mathrm{mM}$ Tris- $\mathrm{HCl} \mathrm{pH}$ 8.0, $10 \mathrm{mM}$ EDTA). The cells were lysed using $300 \mu \mathrm{l} 2$ ( $200 \mathrm{mM} \mathrm{NaOH}, 1 \%$ SDS) followed by a 5 minute incubation at room temperature. To precipitate the protein and cell debris, the viscous cell suspension was gently mixed with $300 \mu \mathrm{l} 3$ ( $3 \mathrm{M}$ potassium acetate, pH 5.5) and placed on ice for 10 minutes. The solution was centrifuged for 15 minutes at $8,170 \times g$, and the supernatant was immediately transferred to a fresh tube. The DNA was precipitated by adding $675 \mu 1$ isopropanol and 
microcentrifuging at $18,500 \times \mathrm{g}$ and $4^{\circ} \mathrm{C}$ for 30 minutes. The DNA pellet was then washed with $70 \%$ ethanol, dried under vacuum, and resuspended in 20 $\mu \mathrm{TE}$.

The plasmid DNA used for sequencing was isolated from E. coli DH5 $\alpha$ strain using the Maxi Qiagen Plasmid Kit (Qiagen Inc.). The DNA used for $B$. thuringiensis electroporation experiments was purified from E. coli GM2163 using the Midi Qiagen Plasmid Kit.

\section{DNA Methods}

Polymerase chain reaction. $B$. thuringiensis cells were used as a PCR template in this study. The cells were grown overnight on a solid medium. A single colony was resuspended in $15 \mu$ sterile water, boiled for 10 minutes, and then centrifuged for 5 minutes. Each PCR reaction contained $2 \mu \mathrm{l}$ of the supernatant from the boiled cells, $1 \times$ PCR buffer [100 mM Tris- $\mathrm{HCl} \mathrm{pH} 8.3,500$ $\mathrm{mM} \mathrm{KCl}, 15 \mathrm{mM} \mathrm{MgCl}$, $0.1 \%$ (wt/vol) gelatin], $200 \mu \mathrm{M}$ deoxyribonucleoside triphosphates (dNTP's; $1.25 \mathrm{mM}$ of dATP, dCTP, dGTP, and dTTP), $1 \mu \mathrm{M}$ LacNHS1 primer, $1 \mu \mathrm{M}$ LacNHS2 primer, and 2.5 units AmpliTaq DNA polymerase (Perkin-Elmer Cetus, Norwalk, CT). The oligonucleotide primers were designed by Nicole Sinibaldi at Sandoz Agro, Inc. The reactions were run in a DNA Thermal Cycler (Perkin-Elmer Cetus) for 25 cycles. Each cycle consisted of 1 minute at $94^{\circ} \mathrm{C}$ (denaturation), 2 minutes at $55^{\circ} \mathrm{C}$ (hybridization), and 3 minutes at $72^{\circ} \mathrm{C}$ (extension). The PCR products were analyzed by agarose gel electrophoresis. 
Agarose gel electrophoresis. The PCR products and restriction enzyme digests of plasmids were analyzed by horizontal agarose gel electrophoresis. DNA was mixed with 0.1 volume $10 x$ loading dye $(0.4 \%$ bromophenol blue, $0.4 \%$ xylene cyanol, $50 \%$ glycerol), loaded onto a $0.8 \%$ agarose gel in $1 \times$ TBE (1.08\% Tris-base, $0.55 \%$ boric acid, $2 \mathrm{mM}$ EDTA, $\mathrm{pH} 8.0$ ) containing $0.5 \mu \mathrm{g} / \mathrm{ml}$ of ethidium bromide, and run on a Submarine Agarose Gel Unit (Hoefer Scientific Instruments, San Francisco, CA). The gel was then photographed on a short wavelength UV box (UVP, Inc., San Gabriel, CA).

To visualize the plasmids in B. thuringiensis strains, the plasmid DNA $(10 \mu 1)$ was added to $2 \mu \mathrm{l}$ of $6 \mathrm{x}$ gel loading buffer $(0.24 \%$ bromophenol blue, $0.24 \%$ xylene cyanol, $30 \%$ glycerol, $10 \mu \mathrm{g} / \mathrm{ml}$ RNAse), loaded on a vertical gel containing $0.8 \%$ agarose in $1 \times$ TBE buffer, and run at $30 \mathrm{~mA}$ for 3 hours on an Adjustable Slab Gel System (C.B.S. Scientific Company, Inc., Del Mar, CA). The gel was transferred to a staining solution (1x TBE with $0.5 \mu \mathrm{g} / \mathrm{ml}$ ethidium bromide) and incubated with slow shaking for 20 minutes. The gel was destained in water briefly and then photographed on a short wavelength UV box.

DNA sequencing. The Sequenase Version 2.0 DNA Sequencing Kit (United States Biochemical, Cleveland, $\mathrm{OH}$ ) was used to sequence the cloned B. thuringiensis chromosomal fragments using the procedure described by the manufacturer. The DNA sequences were then compared to all the known sequences in GenBank using the FastA program of GCG version 7.0 (Genetics Computer Group, Inc., Madison, WI). The GCG program was also used for 
translating the DNA sequence and calculating the molecular weight of the protein product.

\section{Preparation of Competent Cells}

B. thuringiensis competent cells. The culture was grown overnight on an LB plate. A loopfull of individual colonies from the overnight culture was used to inoculate $100 \mathrm{ml}$ of BHIS medium in a $1 \mathrm{~L}$ flask. The culture was grown at $37^{\circ} \mathrm{C}$ with shaking until it reached an OD600 of $0.2-0.3$. The cells were transferred to a prechilled $250 \mathrm{ml}$ bottle and kept on ice for the remainder of the experiment. The culture was centrifuged for 7 minutes at $6,480 \times \mathrm{g}$ and $4^{\circ} \mathrm{C}$. The pellet was washed once in $100 \mathrm{ml}$ and twice in $10 \mathrm{ml}$ of ice cold HEPES [N-(2-hydroxyethyl)piperazine-N'-(2-ethanesulfonic acid)]/sucrose wash solution (0.5 $\mathrm{M}$ sucrose and $5 \mathrm{mM}$ HEPES at $\mathrm{pH} 7.0)$. The cells were then resuspended in $10 \mathrm{ml}$ of the HEPES/sucrose solution and 2.5 $\mathrm{ml}$ of $50 \%$ glycerol. The competent cells were placed in prechilled $1.7 \mathrm{ml}$ microfuge tubes $\left(400 \mu \mathrm{l}\right.$ of cells per tube), frozen on dry ice, and kept at $-80^{\circ} \mathrm{C}$ for long term storage.

High efficiency E. coli GM2163 electro-competent cells. E. coli strain GM2163 was grown overnight on an LB plate. A single colony was used to inoculate $30 \mathrm{ml} \mathrm{SOB}$ medium. The cells were grown overnight at $300 \mathrm{rpm}$. Two hundred milliliters of SOB in a 2 L flask were inoculated with $8 \mathrm{ml}$ of the overnight culture and incubated at $37^{\circ} \mathrm{C}$ and $300 \mathrm{rpm}$ to an OD550 of 0.3. The culture was placed on ice for 15 minutes, centrifuged at $3,840 \times \mathrm{g}$ and $4^{\circ} \mathrm{C}$ for 5 minutes, and the pellet was resuspended in $64 \mathrm{ml}$ of transformation 
buffer $1\left(1.2 \% \mathrm{RbCl}, 0.99 \% \mathrm{MnCl}_{2} \cdot 4 \mathrm{H}_{2} \mathrm{O}, 30 \mathrm{mM}\right.$ potassium acetate $\mathrm{pH} 5.8$, $0.25 \% \mathrm{CaCl}_{2} \cdot 2 \mathrm{H}_{2} \mathrm{O}, 15 \%$ glycerol). After a 15 minute incubation on ice, the cells were centrifuged at $3,840 \times \mathrm{g}$ and resuspended in $16 \mathrm{ml}$ of transformation buffer 2 (10 mM MOPS pH 7.0, 0.12\% RbCl, $1.1 \% \mathrm{CaCl}_{2} \cdot 2 \mathrm{H}_{2} \mathrm{O}, 15 \%$ glycerol). The competent cells were transferred to microcentrifuge tubes, frozen on dry ice, and placed in the $-80^{\circ} \mathrm{C}$ freezer.

E. coli DH5 $\alpha$ and HB101 competent cells. The strains were grown on LB agar for 16-18 hours. A few colonies were used to inoculate $100 \mathrm{ml} \mathrm{LB}$ in 1L Erlenmeyer flasks. The liquid cultures were grown at $37^{\circ} \mathrm{C}$ and $300 \mathrm{rpm}$. Once the cultures reached an OD 600 of 0.2 , they were placed on ice for 15 minutes and then centrifuged for 10 minutes at $5,520 \times \mathrm{g}$ and $4^{\circ} \mathrm{C}$. The cells were resuspended in $50 \mathrm{ml}\left(1 / 2\right.$ volume) $0.05 \mathrm{M} \mathrm{CaCl}_{2}$, incubated on ice for 20 minutes, and centrifuged as described above. The competent cells were then resuspended in $5 \mathrm{ml}$ (1/20 volume) $0.05 \mathrm{M} \mathrm{CaCl}_{2}$ containing $20 \%$ glycerol, placed into microfuge tubes ( $100 \mu \mathrm{l}$ per tube), and frozen on dry ice. The cells were stored at $-80^{\circ} \mathrm{C}$.

\section{B. thuringiensis and E. coli Transformation}

Electroporation of $B$. thuringiensis. The $B$. thuringiensis competent cells $(200 \mu \mathrm{l})$ were mixed with $10 \mu \mathrm{l}$ of DNA (1-5 $\mu \mathrm{g})$ in a prechilled $0.2 \mathrm{~cm}$ gap electrode Gene Pulser Cuvette and exposed to the electrical current in the Gene Pulser electroporation apparatus (Bio-Rad Laboratories, Richmond, CA). This device consists of a pulse controller and a capacitance extender. The parameters for the electroporation of HD1Mit9 were $1.2 \mathrm{kV}, 3 \mu \mathrm{F}, \Omega=\infty$, and 
for Cry-B were $1.05 \mathrm{kV}, 25 \mu \mathrm{F}, \Omega=\infty$. The cells were immediately transferred to $5 \mathrm{ml} \mathrm{BHIS} \mathrm{in} \mathrm{a} 125 \mathrm{ml}$ flask and grown at $30^{\circ} \mathrm{C}$ and $250 \mathrm{rpm}$. After three hours of growth, the cells were transferred to LB agar plates containing Tet 10 . The plates were incubated overnight at $30^{\circ} \mathrm{C}$ and the transformants were restreaked onto fresh $\mathrm{LB}$ Tet ${ }^{10}$ plates.

Electroporation of $E$. coli strain GM2163. The frozen competent cells were thawed at room temperature. Approximately $50 \mu \mathrm{l}$ of competent cells and $4 \mu \mathrm{l}$ DNA (1-2 $\mu \mathrm{g})$ were mixed in a $1.5 \mathrm{ml}$ Eppendorf tube and incubated on ice for 1 minute. The mixture of cells and DNA was transferred to a prechilled $0.2 \mathrm{~cm}$ gap electrode cuvette and pulsed in the high voltage Gene Pulser electroporation apparatus. The settings used were $25 \mu \mathrm{F}, 2.5 \mathrm{kV}$, and $200 \Omega$. Immediately following the electroporation, the cells were transferred to $1 \mathrm{ml} \mathrm{SOC}$ medium in a $17 \times 100 \mathrm{~mm}$ polypropylene tube (VWR Scientific, San Francisco, CA) and incubated at $37^{\circ} \mathrm{C}$ and $225 \mathrm{rpm}$ for 1 hour. The cells were then transferred to LB agar containing Amp 75 and grown overnight.

Transformation of $E$. coli strains DH5 $\alpha$ and HB101. The frozen competent cells ( $100 \mu \mathrm{l} /$ tube) were thawed at room temperature, mixed with 0.5-1 $\mu \mathrm{g}$ of DNA, and incubated on ice for 20 minutes. The mixture was heated at $42^{\circ} \mathrm{C}$ for 90 seconds and then placed on ice for 10 minutes. The cells were transferred to $900 \mu \mathrm{l}$ of $\mathrm{LB}$ and incubated at $37^{\circ} \mathrm{C}$ and $250 \mathrm{rpm}$ for 1 hour. The sample was transferred to LB agar containing Amp 75 and grown overnight. The transformants were restreaked onto fresh LB Amp 75 plates. 


\section{Determination of pLTV1 Stability in $B$. thuringiensis}

The HD1Mit9/pLTV1 strain was grown overnight on an LB plate containing Tet ${ }^{10}$. Several colonies from the overnight plate were used to inoculate $15 \mathrm{ml} \mathrm{LB}$ containing Tet 10 . The culture was grown at $30^{\circ} \mathrm{C}$ to an OD600 of 0.4 . The cells were centrifuged at 7,000 $\mathrm{xg}$ and washed in $10 \mathrm{ml} \mathrm{LB}$ to remove the antibiotic. One hundred fifty microliters of the washed cells were used to inoculate $15 \mathrm{ml} \mathrm{LB}$ in four $125 \mathrm{ml}$ flasks. The cells were grown at four different temperatures, $30^{\circ} \mathrm{C}, 37^{\circ} \mathrm{C}, 40^{\circ} \mathrm{C}$, and $42^{\circ} \mathrm{C}$ to an $\mathrm{OD} 600$ of 0.6 0.8. Various dilutions of each culture were plated onto LB plates containing Ery 0.05 and incubated overnight at the same temperatures. The colonies grown on these plates were patched onto LB and LB Tet ${ }^{10}$ plates. The percentage of bacteria in the population that contained the plasmid was determined by dividing the number of colonies which grew on LB Tet ${ }^{10}$ by the total number of colonies.

\section{Preparation of Tn917 Insertion Libraries}

The B. thuringiensis HD1Mit9 strain containing plasmid pLTV1 was grown on an LB plate containing Tet ${ }^{10}$. Two to three colonies were used to inoculate $10 \mathrm{ml}$ Penassay broth containing Ery0.15. After 90 minutes of growth at $30^{\circ} \mathrm{C}$ and $300 \mathrm{rpm}$, the concentrations of antibiotics in the culture were increased to Ery ${ }^{1}$ and $\mathrm{Lm}^{25}$. When the culture reached an OD595 of 0.5, a $100 \mu \mathrm{l}$ portion was added to $10 \mathrm{ml}$ fresh Penassay broth containing Ery ${ }^{1}$ and $\mathrm{Lm}^{25}$. After 16 hours of growth at $39^{\circ} \mathrm{C}$ and $300 \mathrm{rpm}$, the culture was diluted 1:15 into $10 \mathrm{ml}$ Penassay broth containing Ery ${ }^{1}$ and $\mathrm{Lm}^{25}$ and grown with moderate shaking at $39^{\circ} \mathrm{C}$ until it reached an OD595 of 2.0. The cells were 
pelleted by centrifugation $\left(4,000 \times \mathrm{g}, 4^{\circ} \mathrm{C}\right)$, resuspended in $500 \mu \mathrm{l}$ of Penassay broth containing Ery ${ }^{1}$ and $30 \%$ glycerol, and frozen on dry ice. The libraries were stored at $-80^{\circ} \mathrm{C}$.

To identify colonies that contained a Tn917 insertion, the $10^{-3}$ and $10^{-4}$ dilutions of the libraries were plated onto Penassay plates containing Ery 5 and grown at $39^{\circ} \mathrm{C}$ for 16 hours. The individual colonies were then patched onto LB plates each containing different antibiotics $\left(\operatorname{Tet}^{10}, \mathrm{Lm}^{25}, \mathrm{Ery} 5\right)$ and grown overnight at $30^{\circ} \mathrm{C}$. The colonies that grew only on LB Lm 25 and LB Ery 5 but not LB Tet ${ }^{10}$ contained Tn917 insertions. These colonies were grown on CYS plates and examined microscopically for their ability to sporulate.

\section{Transduction}

Preparation of phage lysate. The donor strains, sporulation mutants HD1Mit9::Tn917 \#1, 2, and 3, were grown on an LB plate containing Ery 5 at $30^{\circ} \mathrm{C}$ overnight (16-18 hours). Two to three colonies were used to inoculate 10 $\mathrm{ml} \mathrm{LB}$ containing $0.4 \%$ glycerol. The culture was incubated at $30^{\circ} \mathrm{C}$ and 300 rpm to an OD600 of 1.6. To infect the cells with the phage CP-51ts45, two different amounts of the phage lysate, $1.2 \times 10^{6}$ and $1.8 \times 10^{6}$ plaque forming units (PFU), were added to $2 \times 10^{7}$ cells in $3 \mathrm{ml}$ PA soft agar which was previously equilibrated to $50^{\circ} \mathrm{C}$. The mixtures were then poured onto PA plates. The plates were incubated at $30^{\circ} \mathrm{C}$ for over 16 hours. The top agar, which contained hundreds of plaques in a lawn of cells, was collected in $6 \mathrm{ml}$ of PA medium. The phage lysate was kept at $16^{\circ} \mathrm{C}$ for $3-4$ hours, centrifuged $\left(4,000 \times \mathrm{g}, 5\right.$ minutes, $\left.16^{\circ} \mathrm{C}\right)$, and the supernatant was filter-sterilized using a 
$0.45 \mu$ filter (VWR Scientific). The phage lysate was stored at $16^{\circ} \mathrm{C}$ for long term storage.

To determine the titer of the phage lysate, dilutions of the lysate were made in sterile $1 \%$ peptone and mixed with $2 \times 10^{7}$ HD1Mit9 cells. The phage/cells mixture was then mixed with $3 \mathrm{ml}$ PA soft agar and poured onto PA plates. The HD1Mit9 cells were prepared using the same protocol described for preparation of the donor strain. The plates were incubated at $30^{\circ} \mathrm{C}$ for 16 hours and plaques were counted.

Generalized transduction. The recipient strain (HD1Mit9) was grown in $10 \mathrm{ml} \mathrm{LB}$ at $30^{\circ} \mathrm{C}$ for $16-18$ hours. Two hundred milliliters of LB were inoculated with $1.5 \mathrm{ml}$ of the overnight culture and grown at $30^{\circ} \mathrm{C}$ and 300 $\mathrm{rpm}$ to an $\mathrm{OD} 600$ of 1.3 . The cells were centrifuged $\left(7,520 \times \mathrm{g}, 4^{\circ} \mathrm{C}, 15\right.$ minutes $)$ and resuspended in LB at a concentration of $1.3 \times 10^{9}$ colony forming units (CFU)/ml (approximately 50 fold concentrated). The transduction mixture, which contained $3 \times 10^{8} \mathrm{CFU}$ of the recipient cells and $3 \times 10^{8} \mathrm{PFU}$ from the phage lysate, was incubated at $37^{\circ} \mathrm{C}$ and $250 \mathrm{rpm}$ for 30 minutes. The cell/phage suspension was spread on HA Millipore membranes (Millipore Corporation, Bedford, MA), placed on LB plates containing Ery 0.15 , and incubated at $37^{\circ} \mathrm{C}$ for 4 hours. The membranes were then transferred to LB plates containing Ery 5 and incubated at $37^{\circ} \mathrm{C}$ for $18-20$ hours.

\section{Cloning the Chromosomal DNA Adjacent to Transposon Insertions}

The chromosomal DNA (11-14 $\mu \mathrm{g})$ was digested with a restriction enzyme as follows. The reactions contained $30-50$ units of enzyme in a $1 \mathrm{x}$ 
reaction buffer and were incubated overnight in a $37^{\circ} \mathrm{C}$ water bath. The $10 \mathrm{x}$ enzyme buffers used were REact 2 ( $500 \mathrm{mM}$ Tris- $\mathrm{HCl} \mathrm{pH} 8.0,100 \mathrm{mM} \mathrm{MgCl}$, $500 \mathrm{mM} \mathrm{NaCl}$ ), REact 3 (500 mM Tris-HCl pH 8.0, $100 \mathrm{mM} \mathrm{MgCl}, 1 \mathrm{M} \mathrm{NaCl}$ ), and NEB 3 [500 mM Tris- $\mathrm{HCl} \mathrm{pH} 8.0,100 \mathrm{mM} \mathrm{MgCl} 2,10 \mathrm{mM}$ dithiothreitol (DTT), $1 \mathrm{M} \mathrm{NaCl}$ ]. The REact 2, REact 3, and NEB 3 buffers were used for the $X b a I, E c o R I$, and BspEI enzymes, respectively. The enzymes were inactivated by heating for 40 minutes at $70^{\circ} \mathrm{C}$.

The digested DNA was ligated in a $100 \mu \mathrm{l}$ volume using 16 units of T4 DNA Ligase and $20 \mu 1$ of $5 x$ Ligase Reaction Buffer [ $50 \mathrm{mM} \mathrm{MgCl}_{2}, 25 \%$ (wt/vol) polyethylene glycol 8000, $5 \mathrm{mM}$ ATP, $5 \mathrm{mM}$ DTT, $250 \mathrm{mM}$ Tris- $\mathrm{HCl}$ $\mathrm{pH} 7.6]$ and incubated overnight at $16^{\circ} \mathrm{C}$. The resulting ligation mixtures were used to transform $100 \mu \mathrm{l}$ E. coli HB101 competent cells. The ampicillinresistant transformed colonies were isolated after 16 hours of growth on LB agar containing Amp75. The plasmid DNA was extracted from the HB101 transformants, transferred to $E$. coli DH5 $\alpha$ or GM2163, and then analyzed by restriction endonuclease digestion. The plasmid DNA was found to be degraded and extremely unstable in the HB101 strain. To overcome this problem, the plasmids were transferred to DH5 $\alpha$ or GM2163.

\section{Characterization of Mutant Spores}

The wild type and the mutant strains were grown in $100 \mathrm{ml} \mathrm{CYS}$ medium. The cultures were harvested 48 hours after they reached the stationary phase. The sporulated cultures were then exposed to various treatments, and serial dilutions in $0.1 \%$ peptone were plated onto LB agar and incubated overnight at $30^{\circ} \mathrm{C}$. The colonies arising from the germinated spores 
were counted. The resistance of the spores to heat, lysozyme, chloroform, acetone, toluene, and 1-octanol was determined as described below:

Heat. The cultures were diluted 1:10 in $0.1 \%$ sterile peptone and divided into two equal parts. One part was incubated at $55^{\circ} \mathrm{C}$ and the other at $65^{\circ} \mathrm{C}$ for 45 minutes with occasional mixing.

Lysozyme. The cultures were diluted $1: 100$ in $0.1 \%$ peptone containing $250 \mu \mathrm{g} / \mathrm{ml}$ lysozyme and incubated at $37^{\circ} \mathrm{C}$ for 15 minutes.

Organic solvents. The samples were treated with toluene, 1-octanol, and chloroform using the following protocol. One milliliter of the cultures was mixed with $7 \mathrm{ml}$ of $0.1 \%$ peptone and $2 \mathrm{ml}$ of organic solvent. The mixtures were then vortexed for 1 minute. For the acetone treatment, the cultures were diluted 1:10 in acetone and incubated at room temperature for 15 minutes. 


\section{RESULTS}

To isolate a sporulation-specific gene, $B$. thuringiensis sporulation mutants were produced by transposon-mediated insertional mutagenesis. The interrupted gene was isolated, characterized, and its DNA sequence was compared to the known sporulation genes in B. subtilis.

The B. thuringiensis strain HD1Mit9 was used for transposon mutagenesis. This strain is an acrystalliferous derivative of $B$. thuringiensis subspecies kurstaki HD1 and contains only one 4-mDa plasmid. Most B. thuringiensis strains carry multiple plasmids which encode crystal proteins. Through previous studies, it was found that transposon Tn917 tends to insert into plasmids rather than the chromosome (Nicole Sinibaldi, personal communication). Using a strain that has only one plasmid increased the possibility of transposition into the $B$. thuringiensis chromosome which contains the sporulation genes.

\section{Characterization of $B$. thuringiensis HD1Mit9}

Before strain HD1Mit9 was mutagenized, its sporulation efficiency and antibiotic resistance were examined. Plasmid pLTV1, the transposon delivery vector used in this study, contained several antibiotic resistance genes which could be used to identify the colonies containing a transposon insertion. As a result, it was important to determine whether HD1Mit9 was sensitive to those antibiotics. Also, since the goal of this study was to identify a sporulation gene, HD1Mit9 was examined for its ability to sporulate. Normal 
sporulation would indicate the absence of mutations in the sporulation genes.

To identify the presence of any naturally occurring antibiotic resistance, HD1Mit9 was grown on LB plates containing either Amp ${ }^{75}$, Ery 5 , Ery $50, \mathrm{Cm}^{5}$, $\mathrm{Cm}^{10}$, or Tet ${ }^{10}$. HD1Mit9 was slightly resistant to ampicillin and chloramphenicol, but sensitive to tetracycline and erythromycin. This strain sporulated well in a rich medium (CYS) after three days of incubation at $30^{\circ} \mathrm{C}$.

\section{Transformation of $B$. thuringiensis with Plasmid pLTV1}

Plasmid pLTV1 (Figure 1) constructed by Camilli et al. (1990) was used to transform B. thuringiensis strain HD1Mit9. This plasmid contains transposon Tn917 which was originally isolated from Streptococcus faecalis (Tomich et al., 1980). Tn917 has two 38 base-pair inverted repeats, represented by dark bars in Figure 1, and generates a five base-pair duplication on insertion. It encodes its transposase and confers resistance to the antibiotics erythromycin and lincomycin (Shaw and Clewell, 1985). A unique characteristic of this transposon is that transposition can be induced by a subinhibitory concentration of erythromycin such as $0.15 \mu \mathrm{g} / \mathrm{ml}$ (Tomich et $a l ., 1980)$. This transposon has been modified by addition of the following foreign DNA without affecting the transposition mechanism. It contains a promoterless $E$. coli lacZ gene which can generate transcriptional lacZ fusions when inserted in the correct orientation into a transcriptional unit (Perkins and Youngman, 1986). Bacteria containing such insertions turn blue on X-Gal plates. As a result, lac $Z$ fusions can be used as a phenotypic screen to identify gene insertions (Youngman, 1987). A chloramphenicol acetyltransferase gene 
(CAT) which can be expressed in Bacillus strains, an ampicillin resistance gene for use as a selectable marker in E. coli, and an E. coli origin of replication (ColEI) were also inserted into the Tn917 portion of pLTV1. Furthermore, a cluster of restriction sites, which facilitate the recovery of chromosomal DNA adjacent to Tn917 insertions, were added to the transposon $\operatorname{Tn} 917$.

In addition to Tn917, plasmid pLTV1 contains a tetracycline resistance gene which is expressed in both $E$. coli and B. thuringiensis strains. It also carries the $\mathrm{pE} 194 \mathrm{Ts}$ temperature sensitive origin of replication which inhibits the plasmid replication at temperatures above $37^{\circ} \mathrm{C}$. At elevated temperatures, pLTV1 cannot replicate and the transposon portion of the plasmid is forced into the bacterial chromosome. The resulting insertioncontaining colonies are resistant to erythromycin and sensitive to tetracycline.

Plasmid pLTV1 was isolated from B. subtilis and introduced into HD1Mit9. However, pLTV1 was not stably maintained in HD1Mit9. Due to the presence of a different methylation process in B. subtilis, certain regions of the DNA might become exposed to the restriction endonucleases in $B$. thuringiensis. Therefore, the plasmid DNA may have been digested and lost from the $B$. thuringiensis cells. To circumvent this problem, it was necessary to first cycle the DNA through an appropriate strain. The plasmid was methylation-modified by replicating in E. coli strain GM2163 which lacks both the Dam and Dcm methylates. Previous studies done by Macaluso and Mettus (1991) indicated that the DNA isolated from GM216; was successfully used for transformation of several $B$. thuringiensis strains. However, pLTV1 isolated from E. coli was also unstable in HD1Mit9. Another approach was to 
transform other $B$. thuringiensis strains assuming that DNA would be easily transferred from one $B$. thuringiensis strain to another. As a result, the plasmid DNA isolated from GM2163 was transformed into $B$. thuringiensis strain Cry-B. Cry-B was used because it contained no plasmids. Once the plasmid pLTV1 had been placed in this strain, it could be isolated without contamination from other plasmids which are present in most $B$. thuringiensis strains. The pLTV1 DNA was then isolated from Cry-B and introduced successfully into strain HD1Mit9.

The presence of plasmid pLTV1 in the HD1Mit9 transformants was confirmed by restriction enzyme digestion and PCR. The results of each experiment were analyzed by agarose gel electrophoresis. The pLTV1 DNA (1 $\mu \mathrm{g})$ was isolated from HD1Mit9 and digested with EcoRI under the conditions described by the manufacturer. Restriction endonuclease analysis indicated the presence of the expected DNA fragments: $4 \mathrm{~kb}, 5 \mathrm{~kb}$, and $11.4 \mathrm{~kb}$ (Figure 2). The PCR primers, LacNHS1 and LacNHS2 (Table 1) which were specific to the lac $Z$ gene on plasmid $\mathrm{pLTV1}$, amplified a $1.5 \mathrm{~kb}$ fragment along with a few other faint bands (Figure 3). Due to the nonspecific binding of the primers to the bacterial DNA, different size fragments were also amplified in the PCR reaction. The $1 \mathrm{~kb}$ DNA ladder (Gibco BRL) was run on the agarose gels as a nucleic acid molecular size standard in the enzyme digestion and the PCR experiments. HD1Mit9 and pLTV1 DNA were used as controls in the PCR experiment. 


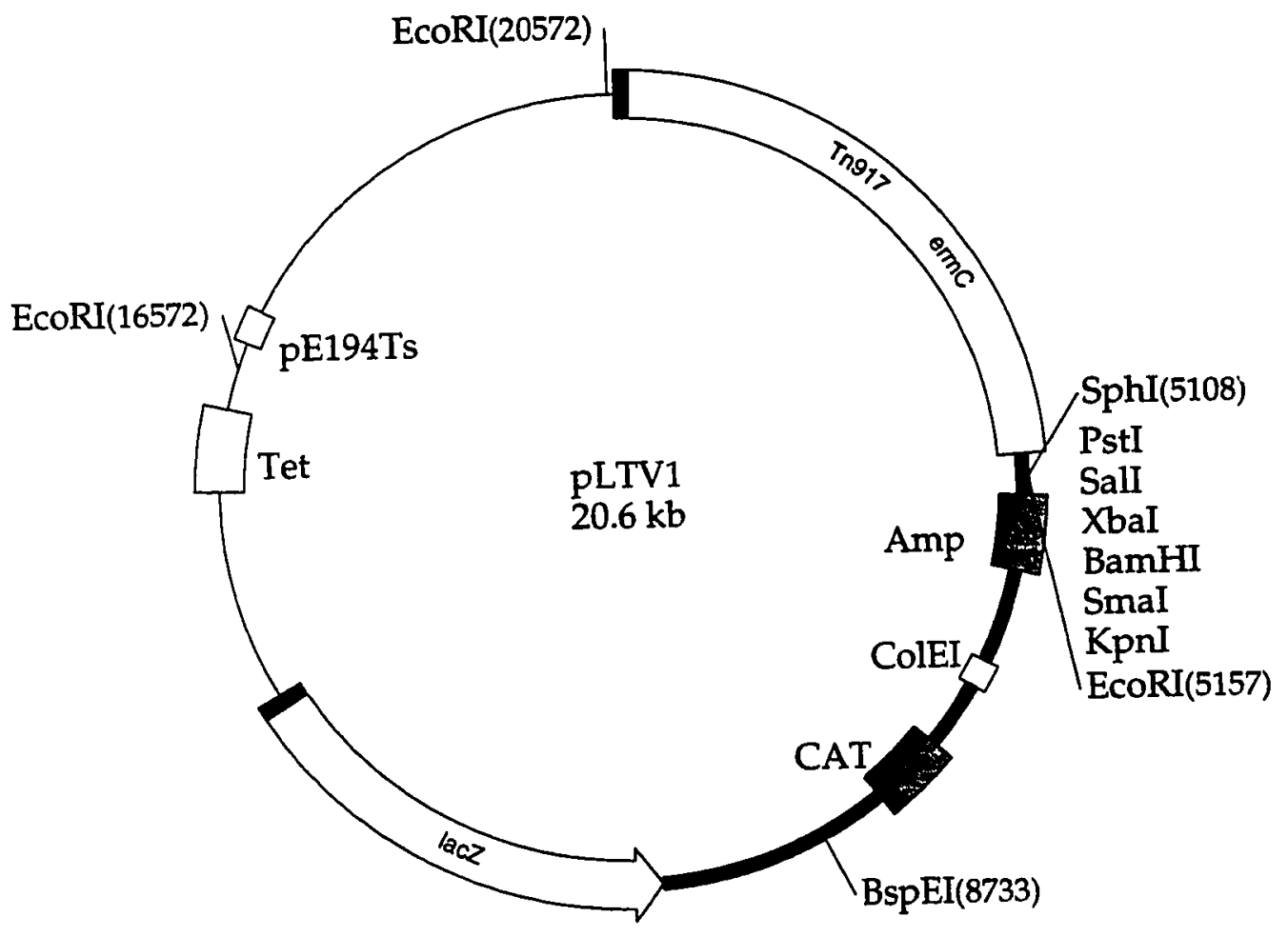

Figure 1. Map of plasmid pLTV1. The two dark bars represent the 38 basepair inverted repeats of $\operatorname{Tn} 917$. 
lane

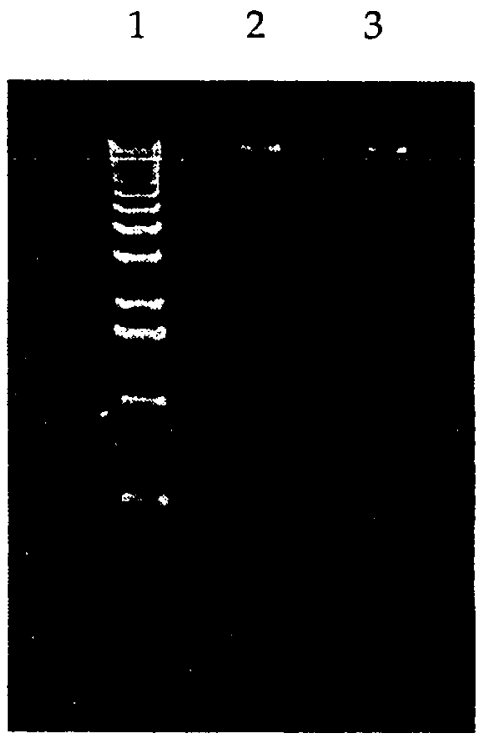

expected bands

$11.4 \mathrm{~kb}$

$5 \mathrm{~kb}$

$4 \mathrm{~kb}$

lane $1 \quad 1 \mathrm{~kb}$ ladder

$2 \mathrm{HD} 1 \mathrm{Mit}$ /pLTV1

$3 \quad$ Cry $^{-B} / \mathrm{pLTV}^{-}$

Figure 2. Agarose gel electrophoresis of plasmid pLTV1 digested with EcoRI. The plasmid DNA was isolated from HD1Mit9 and Cry-B transformants. The $1 \mathrm{~kb}$ ladder contains 23 fragments at the following sizes $(\mathrm{kb})$ :

$\begin{array}{lllll}12.2 & 7.13 & 2.04 & 0.39 & 0.15 \\ 11.2 & 6.11 & 1.64 & 0.34 & 0.13 \\ 10.2 & 5.09 & 1.02 & 0.29 & 0.08 \\ 9.16 & 4.07 & 0.52 & 0.22 & \\ 8.14 & 3.05 & 0.51 & 0.20 & \end{array}$


Table 1. Oligonucleotide primers used for the detection of pLTV1 in $B$. thuringiensis

\begin{tabular}{ll}
\hline Primer & Sequence (5'-3') \\
\hline LacNHS1 & GGCTTTCGCTACCTGGAGAGACGCGCCCGC \\
LacNHS2 & CCAGACCAACTGGTAATGGTAGCGACCGGC \\
\hline
\end{tabular}




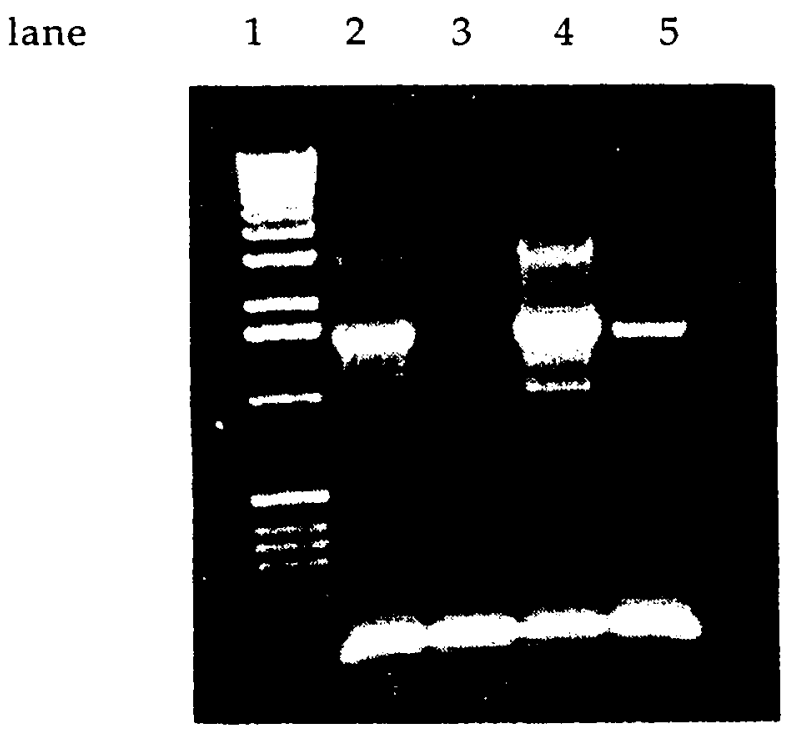

expected band

$1.5 \mathrm{~kb}$

\begin{tabular}{|c|c|c|}
\hline lane & 1 & $1 \mathrm{~kb}$ ladder \\
\hline & 2 & pLTV1 plasmid \\
\hline & 3 & HD1Mit9 \\
\hline & 4 & HD1Mit9/pLTV1 \\
\hline & 5 & Cry-B/pLTV1 \\
\hline
\end{tabular}

Figure 3. Agarose gel analysis of PCR performed to confirm the presence of pLTV1 in B. thuringiensis HD1Mit9 and Cry-B. 


\section{Stability of pLTV1 in HD1Mit9}

Previous studies in B. subtilis indicated that pLTV1 stops replicating at very high temperatures such as $48^{\circ} \mathrm{C}$ (Sandman et al., 1987). However, the maximum temperature used for growing $B$. thuringiensis is approximately $41^{\circ} \mathrm{C}$. As a result, it was important to identify the lowest temperature at which the plasmid failed to replicate in B. thuringiensis. By preventing the replication of pLTV1, colonies with chromosomal insertions can be obtained.

The HD1Mit9/pLTV1 strain was grown at four different temperatures $\left(30^{\circ} \mathrm{C}, 37^{\circ} \mathrm{C}, 40^{\circ} \mathrm{C}, 42^{\circ} \mathrm{C}\right)$ and plated onto LB Ery 0.05 . Single colonies were then patched onto selective media (LB agar containing Ery or Tet). Because the erythromycin and tetracycline resistance genes on PLTV1 were lost at the nonpermissive temperatures, the colonies containing pLTV1 grew in the presence of Ery and Tet, and those that lost the DNA grew only on LB plates. The percentage of cells which retained pLTV1 was determined by dividing the number of colonies which grew on LB Ery or LB Tet by the number of colonies on LB plates (Table 2).

At temperatures above $37^{\circ} \mathrm{C}$, the plasmid was extremely unstable and readily lost from the cells. Based on these results, $39^{\circ} \mathrm{C}$ was chosen for use in the transposition procedure because $B$. thuringiensis grew well at this temperature. The recommended temperature for growth of $B$. thuringiensis is $30^{\circ} \mathrm{C}$. 
Table 2. The percentage of HD1Mit9 cells containing plasmid pLTV1 at various temperatures

\begin{tabular}{ll}
\hline Temperature & $\%$ of cells containing pLTV1 \\
\hline $30^{\circ} \mathrm{C}$ & $96 \%$ \\
$37^{\circ} \mathrm{C}$ & $10 \%$ \\
$40^{\circ} \mathrm{C}$ & $3 \%$ \\
$41^{\circ} \mathrm{C}$ & $0 \%$ \\
\hline
\end{tabular}




\section{Isolation and Characterization of HD1Mit9 Sporulation Mutants}

To obtain mutations in $B$. thuringiensis sporulation genes, a large population of chromosomal Tn917 insertions was prepared. During transposition, the transposon inserts in the B. thuringiensis genome (Figure 4). If the insertion occurs in the middle of a gene, the gene product will probably not be functional. To prepare a library of insertions, the HD1Mit9/pLTV1 strain was grown at a low temperature $\left(30^{\circ} \mathrm{C}\right)$ in the presence of an inducing concentration of erythromycin (Ery0.15). The culture was then diluted into a large volume of medium containing Ery ${ }^{1}$ and $\mathrm{Lm}^{25}$ and grown at a higher temperature $\left(39^{\circ} \mathrm{C}\right)$. As indicated previously, the $\mathrm{pE} 194 \mathrm{Ts}$ temperature-sensitive origin of replication located on plasmid pLTV1 inhibits plasmid replication at high temperatures. After growing the cells at $39^{\circ} \mathrm{C}$, the majority of the surviving cells had a transposon insertion.

In the process of preparing the library, the culture was diluted several times into fresh media. This step could cause the enrichment of particular insertions in the population, making the distribution of insertions less random. In every dilution step, a small number of cells containing the transposon could be transferred and allowed to replicate. As a result, the final culture could contain a large population of cells with insertions in the same gene. To circumvent this problem, ten separate libraries were prepared to ensure that each contained different insertions.

Over $1 \times 10^{4}$ colonies were screened for transposon insertions by plating onto LB plates each containing different antibiotics (Tet ${ }^{10}, \mathrm{Lm}^{25}$, Ery ${ }^{5}$ ). Sixty-three colonies containing a chromosomal insertion were obtained $(0.6 \%)$, and the average frequency of transposition was $6 \times 10^{-3}$. The 
transposition frequency was calculated by dividing the number of tetracyclinesensitive colonies by the number of colonies that grew on LB Ery. The insertcontaining colonies were examined microscopically for the asporogenic phenotype. The colonies were grown on CYS plates for 5-7 days and observed under the microscope for the presence or absence of spores. Only three colonies (5\% of the insertion mutants) were sporulation-defective.

The asporogenic mutants were grown in minimal media to identify auxotrophs and citric acid cycle-defective colonies. If the mutants were auxotrophs or TCA cycle mutants, their sporulation-defective phenotype might be due to a metabolism problem or to the lack of energy needed for completion of the sporulation cycle. However, the three sporulation mutants (HD1Mit9::Tn917 isolates \#1, 2, and 3) grew well on glucose and lactate minimal media indicating that they were not auxotrophs or defective in citric acid cycle enzymes.

To detect the expression of $\operatorname{lac} Z$ on the inserted Tn917, the mutants were grown on LB plates containing X-Gal. The lacZ gene codes for the enzyme B-galactosidase which breaks the B-galactoside, $\mathrm{X}$-Gal, into its component sugars. Bacteria expressing the lac $\mathrm{Z}$ gene form blue colonies in the presence of the X-Gal substrate (Sambrook et al., 1989). In this experiment, a few spots of blue color were seen in the colonies of HD1Mit9::Tn917 isolates \#2 and \#3. However, HD1Mit9::Tn917 \#1 remained white even after four days of incubation, indicating there was no expression of the lac $Z$ gene. One possible explanation for the white color phenotype is that Tn917 was inserted in such a way that the $\operatorname{lac} Z$ gene was not in the same orientation as the transcription unit and therefore was not expressed. 


\section{B. thuringiensis Cell}

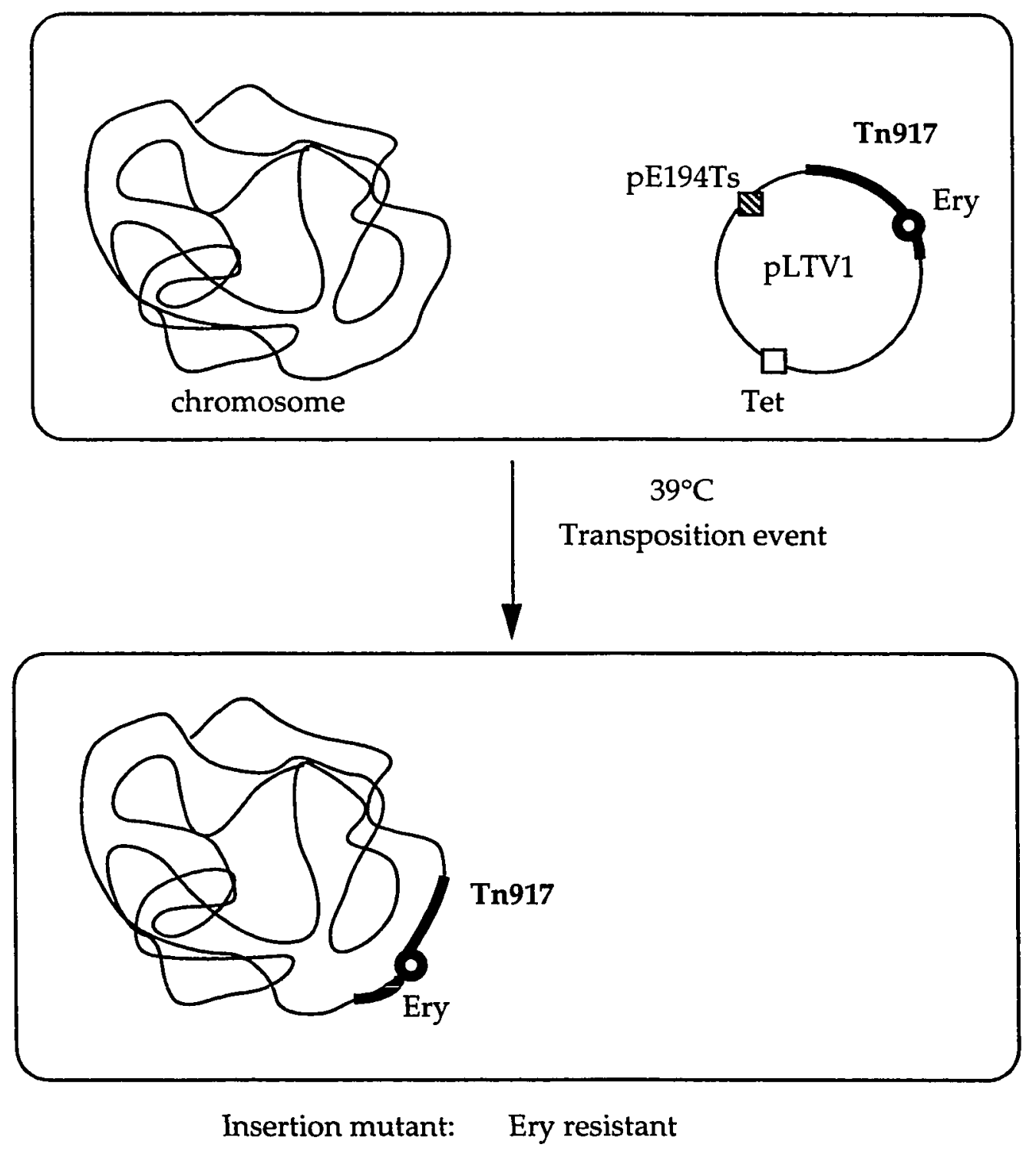

Tet sensitive

Figure 4. Transposition in B. thuringiensis. 


\section{Verification that Tn917 Inserted into a Sporulation Gene}

Generalized transduction was used to confirm Tn917 inserted into a sporulation gene. Phage CP-51ts45 was used for the transduction experiment. This phage is a temperature-sensitive derivative of phage CP-51 which was originally isolated from soil (Thorne, 1968a). Previous studies indicated that phage CP-51 carries out generalized transduction in various Bacillus species such as B. thuringiensis (Thorne, 1978), Bacillus cereus, and Bacillus anthracis (Thorne, 1968b). The advantage of using CP-51ts45 is that the lytic and lysogenic characteristics of this bacteriophage can be controlled by altering the temperature (Curtis Thorne, personal communication). This phage undergoes a lytic cycle at $30^{\circ} \mathrm{C}$ and lysogeny at $37^{\circ} \mathrm{C}$.

Phage lysates were prepared from the three sporulation mutants of HD1Mit9 and used to transduce the wild type HD1Mit9 strain. In this experiment, the phage was used to carry the region of the chromosome containing the Tn917 insertion into the wild type HD1Mit9 strain. Through a homologous recombination event, the DNA flanking Tn917 insertion was inserted into the homologous region of the wild type HD1Mit9 chromosome.

The erythromycin-resistant colonies obtained from transduction were grown on CYS plates for 5 days and observed microscopically for their ability to sporulate. The sporulation-defective phenotype was transferred to HD1Mit9 for only two of the mutants, HD1Mit9::Tn917 \#1 and 2. This result indicated that the sporulation defect in isolates \#1 and 2 was due to a Tn917 insertion in a sporulation gene. However, HD1Mit9::Tn917 \#3 was a sporulation mutant possibly created by a spontaneous mutation in a sporulation gene rather than by a transposon insertion. 


\section{Isolation and DNA Sequence of the Chromosomal DNA Flanking the Tn917 Insertions}

As mentioned above, unique sites in the polylinker or other regions of the transposon can be used to directly clone the DNA adjacent to transposon insertions in E. coli strains. B. thuringiensis chromosomal DNA is digested with an appropriate restriction enzyme, circularized by ligation, and introduced into $E$. coli. Plasmids obtained this way contain the gram negative origin of replication located in the transposon and the ampicillin-resistance gene which can be used as a selectable marker in E. coli. In addition, these plasmids carry a fragment of the $B$. thuringiensis chromosomal DNA adjacent to $\operatorname{Tn} 917$.

As recommended by Youngman (1987), E. coli HB101, which is deficient in recombination and restriction, was used for cloning. The flanking DNA adjacent to one side of the Tn917 insertions in HD1Mit9::Tn917 $\# 1$ and 2 was cloned using EcoRI. These DNA fragments were sequenced and compared to GenBank sequences using GCG on a VAX computer system. The sequence from HD1Mit9::Tn917 \#2 showed no significant similarity to any of the sequences in the GenBank data base. However, isolate \#1 showed high homology with the $B$. subtilis spoVJ gene. As a result, the chromosomal fragments on both sides of the inserted Tn917 in mutant \#1 were cloned using BspEI and XbaI. The cloning strategy shown in Figure 5 was based on the method used by Youngman (1987). 


\section{B. thuringiensis Chromosome}
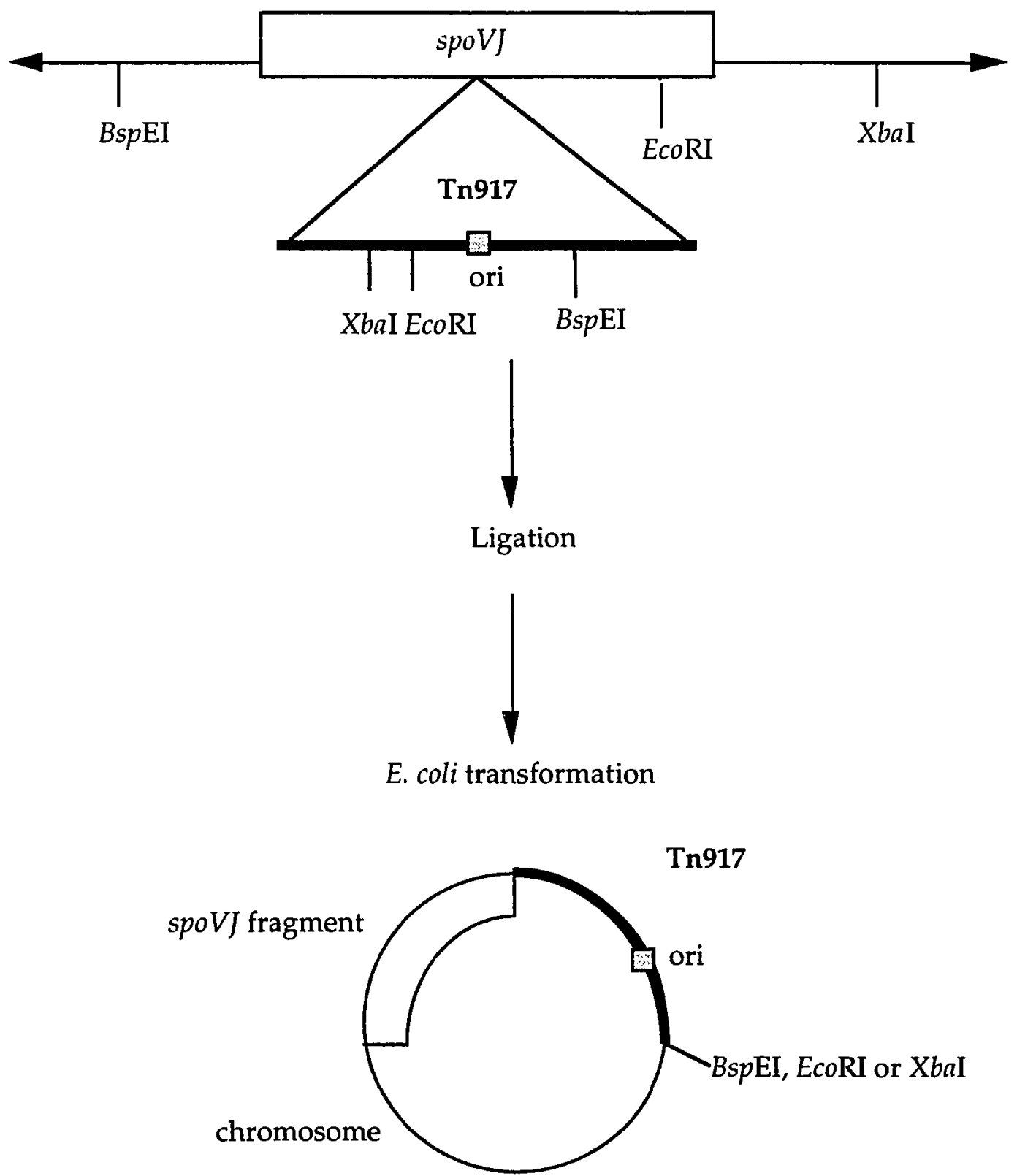

Figure 5. Cloning strategy used to isolate the HD1Mit9::Tn917 \#1 sporulation gene interrupted by Tn917. The E. coli origin of replication (ori) is indicated by a gray square. 
The plasmids obtained from EcoRI, XbaI, and BspEI digests were called pSB1211, pSB1212, and pSB1213, respectively. Plasmids pSB1211 and pSB1212 contained the lacZ gene and pSB1213 carried the unmodified portion of transposon Tn917 (Figures 6, 7, and 8). Plasmids pSB1211, pSB1212, and pSB1213 were digested with various enzymes (EcoRI, BglI, PvuII, BspEI, HindIII, $\mathrm{XbaI}$ ) to determine the size of the $B$. thuringiensis chromosomal fragments (Figures 9, 10 and 11). Based on these experiments, pSB1211, pSB1212, and pSB1213 contained approximately $0.47 \mathrm{~kb}, 5.66 \mathrm{~kb}$, and $4.23 \mathrm{~kb}$, respectively, of the chromosomal DNA flanking Tn917. These plasmids were later used for sequencing the entire cloned sporulation gene. The sequence of the $\mathrm{NH}_{2}$-terminal coding region was obtained using plasmid pSB1213, and the $\mathrm{COOH}$-terminal coding region was sequenced using plasmids pSB1211 and PSB1212.

Both strands of the cloned gene (Figures 6, 7, and 8) from HD1Mit9::Tn917 \#1 were sequenced using the primers listed in Table 3. Each primer was designed based on the sequence previously obtained from the sporulation gene. The locations of the oligonucleotides are shown on the sporulation gene interrupted with transposon Tn917 in the B. thuringiensis chromosome in Figure 12. The sequence of the sporulation gene was compared to that of spoVJ in B. subtilis. Based on the computer analysis, the sequenced gene shared significant sequence identity with the $B$. subtilis spoVI gene both at the DNA and protein level (Table 4). As a result, the isolated gene was believed to be the spoVJ gene from $B$. thuringiensis. 


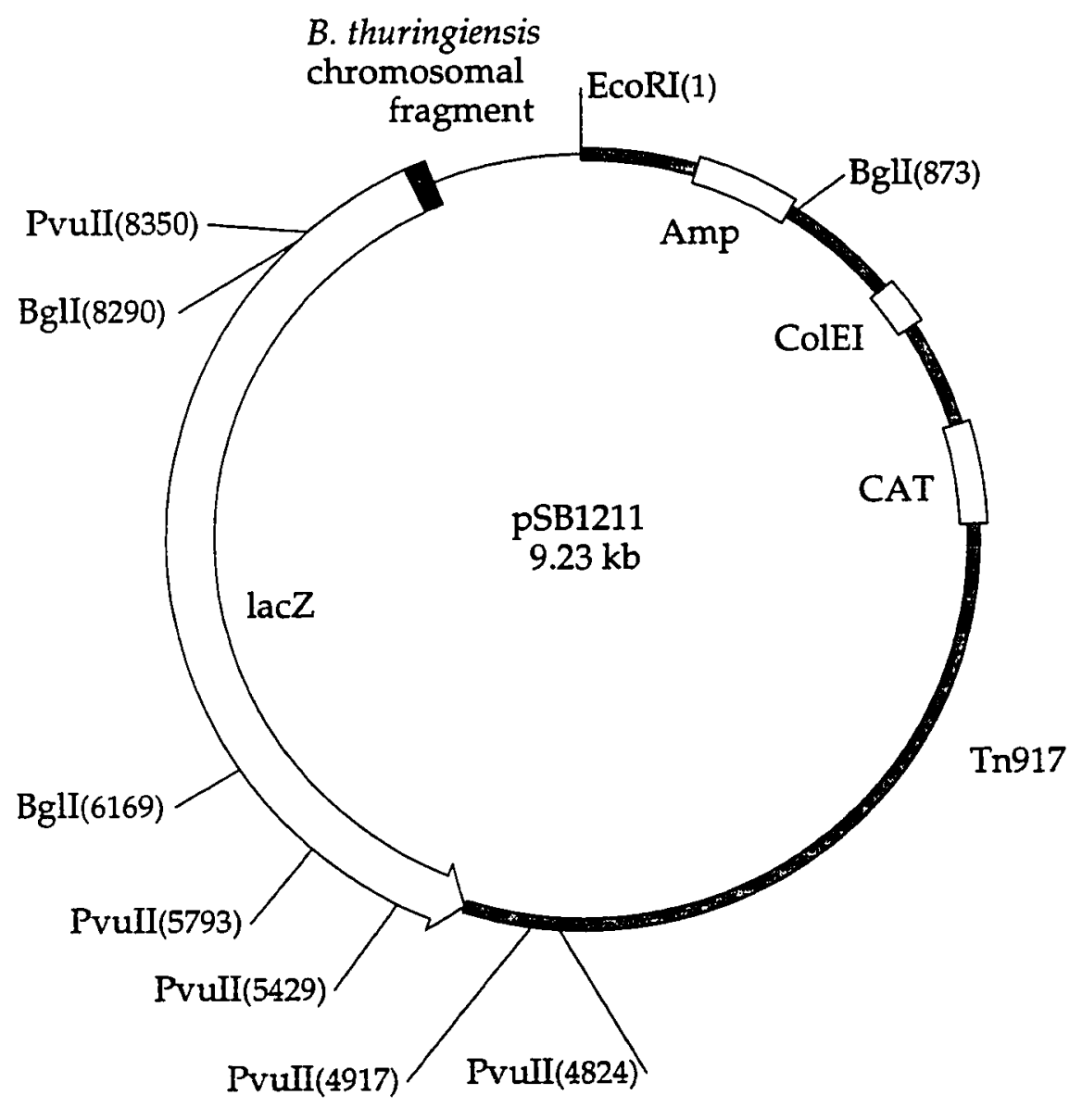

Figure 6. Map of plasmid pSB1211. The locations of the restriction sites for the enzymes used are indicated. 


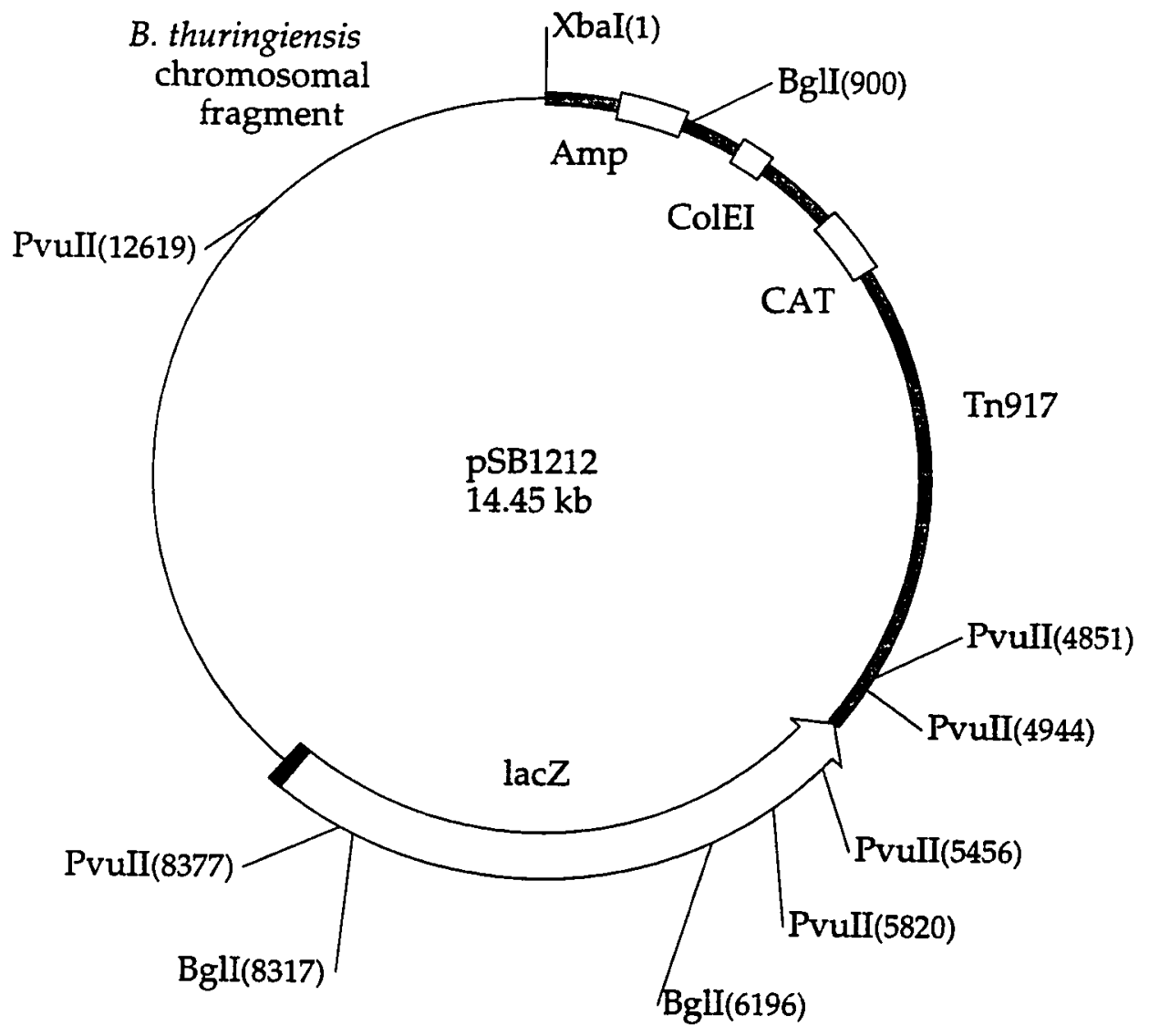

Figure 7. Map of plasmid pSB1212. The locations of the restriction sites for the enzymes used are indicated. 


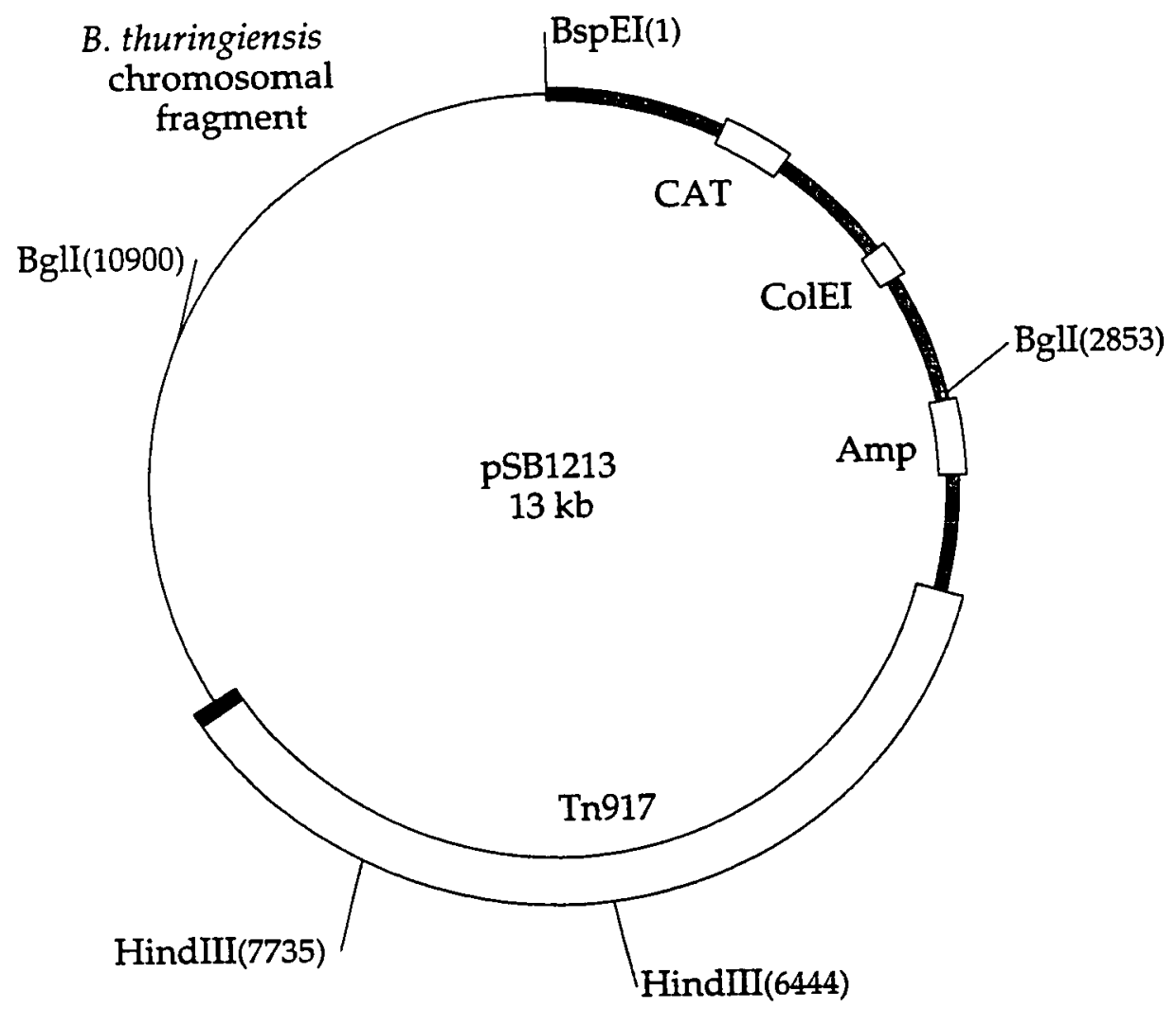

Figure 8. Map of plasmid pSB1213. The locations of the restriction sites for the enzymes used are indicated. 


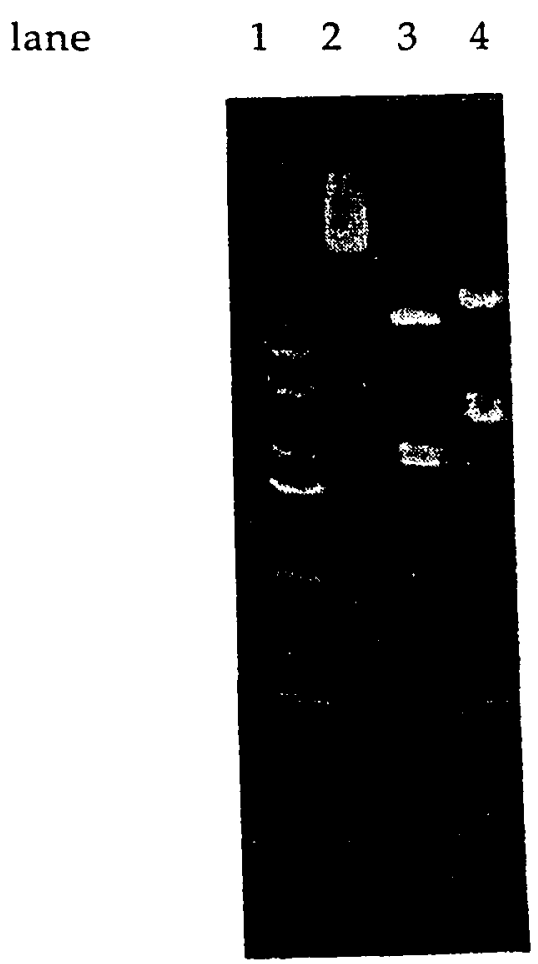

$\begin{array}{rll}\text { lane } & 1 & 1 \text { kb ladder } \\ 2 & \text { EcoRI } \\ 3 & B g l I \\ 4 & P v u I I\end{array}$

Figure 9. Restriction enzyme digests of plasmid pSB1211. 


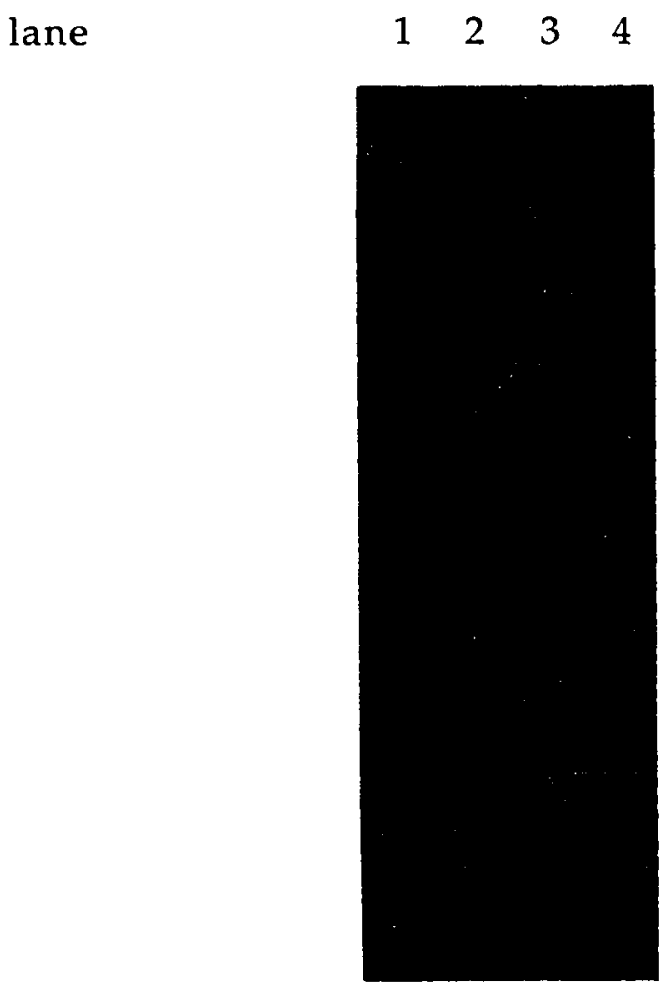

$\begin{array}{lll}\text { lane } & 1 & \text { XbaI } \\ 2 & B g l \mathrm{I} \\ 3 & P v u I I \\ 4 & 1 \mathrm{~kb} \text { ladder }\end{array}$

Figure 10. Restriction enzyme digests of plasmid pSB1212. 


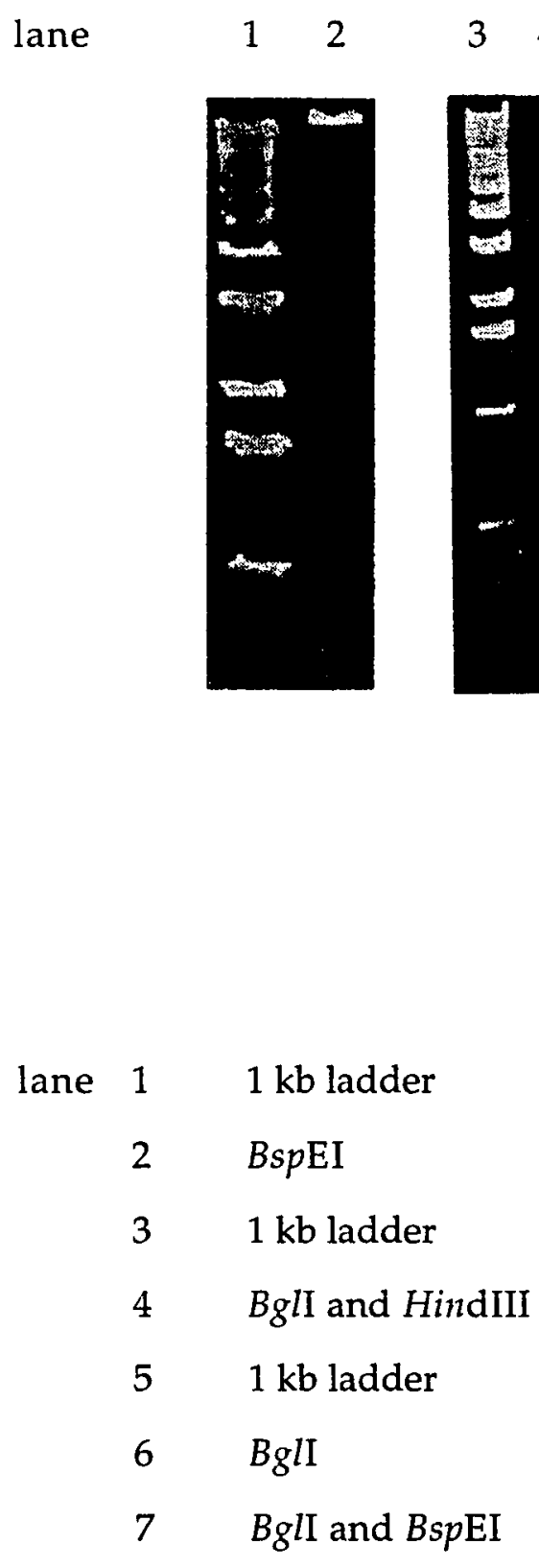

Figure 11. Restriction enzyme digests of plasmid pSB1213. 
Table 3. Primers used for sequencing the $B$. thuringiensis spoVJ gene

\begin{tabular}{ll}
\hline Primer & Sequence (5'-3') \\
\hline MS1 & GAGAGATGTCACCGTCAAG \\
MS2 & CCCTGTACCTGGATTCCC \\
MS3 & GGGAATCCAGGTACAGGG \\
MS4 & CCATCCCAACAAGCTTCCC \\
MS5 & GGGAAGCTTGTTGGGATGG \\
MS6 & CCTGTCCCCCTTGTAAATGC \\
MS7 & GCATTTACAAGGGGGACAGG \\
MS8 & CGCCGTCTACTTACAAGCAGC \\
MS9 & GGTGGTGGGACTATGGAG \\
MS10 & CTCCATAGTCCCACCACC \\
MS11A & CGAGGAGGAGAGAAGGAC \\
MS11rev & GTCCTTCTCTCCTCCTC \\
MS12A & CGAAGTGTACGGTCTGG \\
MS12B & CACGATGCATCG \\
MS13A & CGAAAGAGGCTGAATGG \\
MS13B & GGGCGGTATGTACGG \\
MS13rev & CCGTACATACCGCCC \\
MS14 & GCATCAAATCCATACTCGATATTCC \\
MS14revB & CGAGTATGGATTTGATGCTCG \\
MS16 & GGACACGATCCTAATTCAGC \\
MS16rev & GCTGAATTAGGATCGTGTCC \\
\hline
\end{tabular}


A.

Sporulation gene interrupted with Tn917

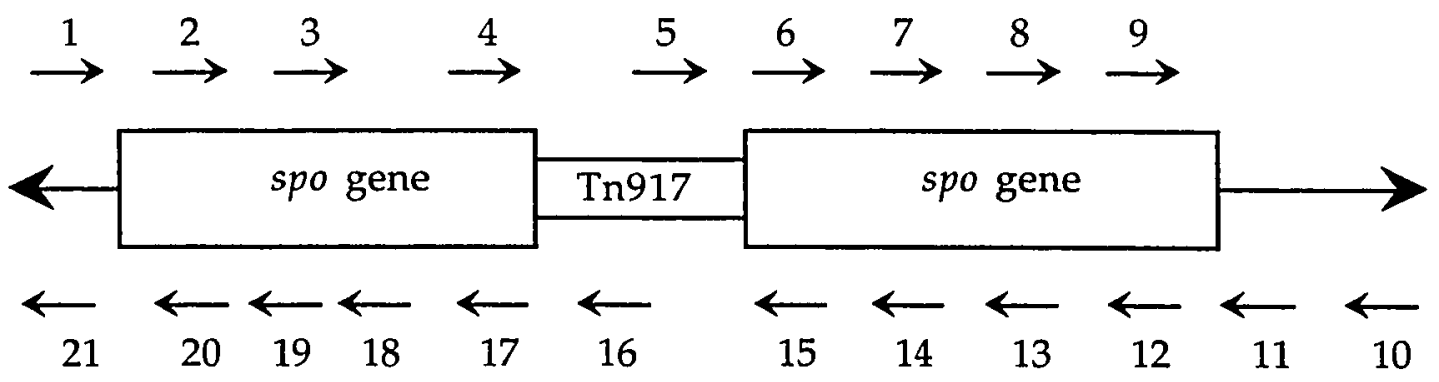

B.

$\begin{array}{cllllll}\text { primer } & 1 & \text { MS16 } & 8 & \text { MS6 } & 15 & \text { MS3 } \\ 2 & \text { MS14 } & 9 & \text { MS9 } & 16 & \text { MS8 } \\ 3 & \text { MS13rev } & 10 & \text { MS12A } & 17 & \text { MS11A } \\ 4 & \text { MS11rev } & 11 & \text { MS12B } & 18 & \text { MS13A } \\ 5 & \text { MS1 } & 12 & \text { MS10 } & 19 & \text { MS13B } \\ 6 & \text { MS2 } & 13 & \text { MS7 } & 20 & \text { MS14revB } \\ 7 & \text { MS4 } & 14 & \text { MS5 } & 21 & \text { MS16rev }\end{array}$

Figure 12. (A) Location of oligonucleotides used for sequencing the $B$.

thuringiensis sporulation gene (spo gene); (B) list of the primers used for sequencing. 
Table 4. Comparison between the B. subtilis spoVJ gene and the cloned sporulation gene from B. thuringiensis HD1Mit9::Tn917 \#1

\begin{tabular}{ll}
\hline Level of comparison & $\%$ identity \\
\hline protein & $70 \%$ \\
DNA & $69 \%$ \\
\hline
\end{tabular}


The sequence of the $B$. thuringiensis spoVJ gene and the amino acid comparison between the SpoVJ in B. thuringiensis and B. subtilis are shown in Figures 13 and 14, respectively. The putative translation start codon of the $B$. thuringiensis spoVJ gene was identified based on the sequence comparison with B. subtilis spoVJ (Figure 13; Foulger and Errington, 1991). The putative ribosome-binding site of spoVJ in B. thuringiensis was recognized on the basis of its homology to the 3 ' terminal region of $B$. subtilis $16 \mathrm{~S}$ rRNA (Figure 13; Moran et al., 1982). The free energy of base-pairing between $16 \mathrm{~S}$ rRNA and the putative spoVJ ribosomal binding site (determined according to Tinoco $e t$ al., 1973) was $-18.2 \mathrm{kcal}$. The distance between the ribosomal binding site and the putative translation initiation codon, calculated according to Moran et al. (1982), was 9 bases. The normal range for the free energy of base pairing in $B$. subtilis is -14 to $-23 \mathrm{kcal}$, and the normal range for spacing between the ribosomal binding site and the start codon is 7-14 bases (Moran et al., 1982).

The molecular mass of the putative spoVJ protein product was 36.7 kDa. According to Foulger and Errington (1991), the B. subtilis spoVJ gene encodes a $36 \mathrm{kDa}$ protein. The amino acid sequence of $B$. subtilis SpoVJ contains consensus sequences present in adenine or guanine mononucleotide binding proteins (Foulger and Errington, 1991; Moller and Amons, 1985; Walker et al., 1982). These sequences were also found in the $B$. thuringiensis SpoVJ protein (Figure 13). Using GCG computer analysis, a region of GC-rich dyad symmetry was found at the end of the $B$. thuringiensis spoVJ coding region. This region is most likely the stem-loop of the transcription terminator (Figure 13). 
Figure 13. Sequence of the B. thuringiensis HD1Mit9 spoVJ gene (following three pages). The nucleotides are numbered on the left side of the sequence. The predicted amino acid sequence of the SpoVJ protein is shown under the nucleotide sequence using the single-letter code. Intervals of ten nucleotides are indicated by dots. The nucleotide sequence of the putative ribosomebinding site is underlined. The predicted transcription terminator stem-loop is underlined by two inverted arrows. The amino acid residues, which may be involved in nucleotide-binding, are shown in boxes. 
1 CAGGTGAAATGAAATCTTCGTTACGAAGTGTACGGTCTGGTTGAATAGA

51 ATCTCCATATTTTTCAATGGATTAGGAATGTTTAGAAAATGATGCATTCT

101 ATTTAGTACAATAAATACACGATGCATCGTTTTTTCTGÄGTAATGTCGAT

151 TCGTTTTAAÄTCGGAAAAGTAATCTTCGTÄGTCTTTTGTÄCAAAGTGTÁ

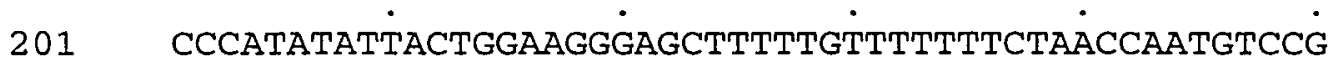

251 AAGTCTTCAÄGTCATAAACATAACGTTTÄATAGTTGAGGGTTTTCGGCC

301 TTTATTCAATAAAAAAATAGAAAAGGCTTGTATTGTATCAंTGGAATTCC.

351 TTGTCTCCAं̈AGTCCCACCÄCCTTAATTATTTCTTATATTATAGCAAACT

401 TTTCTGAAAÄTAGgCATTTACAAGgGGgACAGGAATAATȦATATTTGGTG

451 AGTGGATAAAATGAGGTGATTGTATGGAACAATCGATGCGAAAGAAAAAC $\begin{array}{llllllllllllll}M & E & Q & S & M & R & K & K & N\end{array}$

501 AACAATCAAÄTAATATTGTGTTAAACCATCGAAAGAAAÄTTCTTTGCC $\begin{array}{lllllllllllllllll}N & N & Q & I & N & I & V & L & N & H & R & K & K & I & S & L & P\end{array}$

551 AGCCGCAGAAAATAAAACGGTAATTTCAAÄTGAAACTGCAATTAAACATG $\begin{array}{lllllllllllllllll}A & A & E & N & K & T & V & I & S & N & E & T & A & I & K & H & E\end{array}$

601 AAATGCTGCÄGAGAATTGAAGAAGAGATGGGGAAGCTTGTTGGGATGGAT $\begin{array}{llllllllllllllll}M & L & Q & R & I & E & E & E & M & G & K & L & V & G & M & D\end{array}$

651 GATATAAAAÄAGATAATAAAAgAAATATATGCTTGGATTTATGTGAATAA $\begin{array}{lllllllllllllllll}D & I & K & K & I & I & K & E & I & Y & A & W & I & Y & V & N & K\end{array}$

701 AAAAAGACAÄGAGAAGGGATTGAAGTCAGÄGAAGCAAGTÁCTTCATATGC $\begin{array}{lllllllllllllllll}K & R & Q & E & K & G & L & K & S & E & K & Q & V & L & H & M & L\end{array}$ 
751 TGTTTAAAGGGAATCCAGGTACAGGGAAGACAACTGTTGCTAGAATGATA

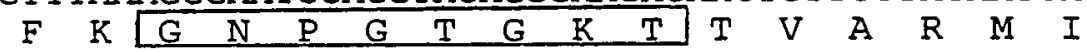

801 GGGAAATTGCTGTTTGAGATGAATATTCTÁTCGAAAGGCCACTTGGTTGA $\begin{array}{lllllllllllllllll}G & K & I & L & F & E & M & N & I & L & S & K & G & H & L & V & E\end{array}$

851 AGCTGAACGTGCTGATCTTGTAGGAGAGTA்CATCGGCCATACAGCTCAAÁ $\begin{array}{lllllllllllllllll}A & E & R & A & D & I & V & G & E & Y & I & G & H & T & A & Q & K\end{array}$

901 AAACAAGAGACTTAATAAAAAAAGCAATGGGAGGTATTTTMTTTTATTGAT

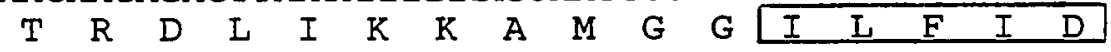

951 GAGGCGTATTCTTTAGCTCGAGGAGGAGAGAAGGACTTTGGAAAAGAAGC $\begin{array}{lllllllllllllllll}E & A & Y & S & L & A & R & G & G & E & K & D & F & G & K & E & A\end{array}$

1001 AATTGATACGCTTGTAAAACATATGGAAGATAAACAACATGGTTTTGTAT $\begin{array}{lllllllllllllllll}I & D & T & L & V & K & H & M & E & D & K & Q & H & G & F & V & I\end{array}$

1051 TGATTTTAGCTGGATATTCAAGAGAGATGÄATCACTTTCTTTCATTAAAT $\begin{array}{llllllllllllllll}I & L & A & G & Y & S & R & E & M & N & H & F & L & S & L & N\end{array}$

1101 CCAGGGCTGCAATCTCGTTTTCCATTTATTATTGAATTTGCGGATTACTC $\begin{array}{lllllllllllllllll}P & G & L & Q & S & R & F & P & F & I & I & E & F & A & D & Y & S\end{array}$

1151 GGTAAATCAGTTGTTGGAAATTGGGAAAAGAATGTATGAÄGATCGTGAAT $\begin{array}{llllllllllllllllll}V & N & Q & I & I & E & I & G & K & R & M & Y & E & D & R & E & Y\end{array}$

1201 ATCAGTTATCGAAAGAGgCTGAATGGAAATTTAGGGATCAंTTTACATGCT $\begin{array}{llllllllllllllll}Q & I & S & K & E & A & E & W & K & F & R & D & H & L & H & A\end{array}$

1251 GTAAAGTATTCGTCGCAAATTACATCGTTTAGTAATGGGCGGTATGTACG $\begin{array}{lllllllllllllllll}V & K & Y & S & S & Q & I & T & S & F & S & N & G & R & Y & V & R\end{array}$

1301 GAATATTGTTGAAAAATCAÄTTCGTACACÄGGGATGCGGTTGTTGCAAG $\begin{array}{lllllllllllllllll}N & I & V & E & K & S & I & R & T & Q & A & M & R & L & L & Q & E\end{array}$ 
1351 AAGATGCCTÁTGATAAAAATTGATTTAATTGGAATATCGAGTATGGATTTE $\begin{array}{llllllllllllllll}D & A & Y & D & K & N & D & L & I & G & I & S & S & M & D & L\end{array}$

1401 ATGCTCGAAGAGGAGACGCACAGTACATAAACTGTGCGTCGATTTTTGTG

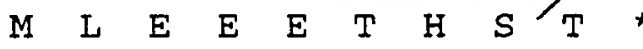

1451 TATAAGTTCGTTTACTCTTTTTTTTCTTTTTCTTGGTGTÁCTTCATGGA

1501 GTGTTCCATTTTAGCGCTCTTTTCGTGTGCTGAATTAGGÄTCGTGTCCAд

1551 ATTGATTTACTGAGCTTTTTTGAGCTCCTTTATTAACGTGGTTTGTCATT

1601 TGTATTCACCंCACTTTAAÄAATTAGTATA்ACATTATATAAAGAAAAA

1651 TCGTTAGAAAAAGA 


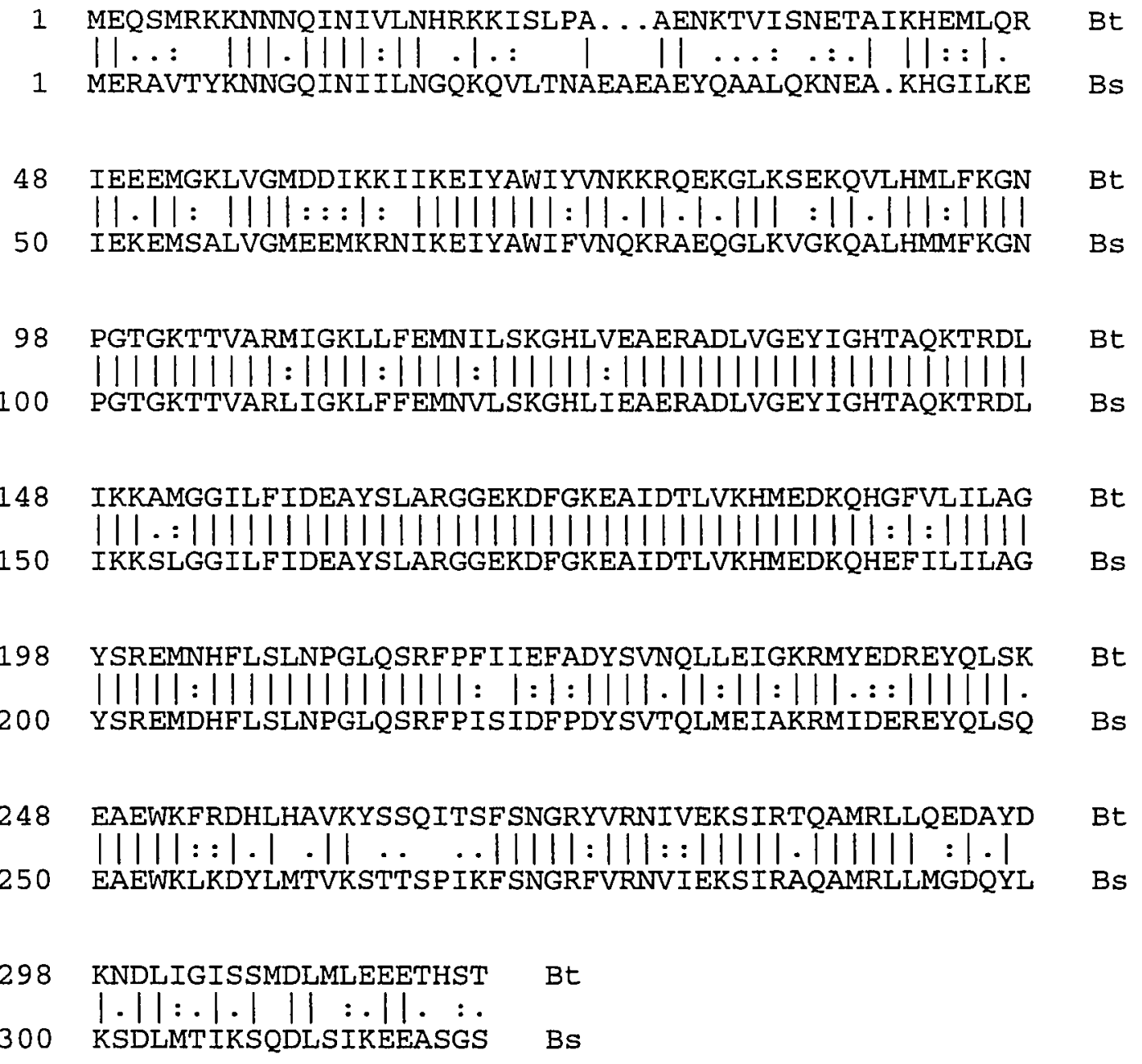

Figure 14. Amino acid comparison between the SpoVJ proteins from $B$. subtilis and $B$. thuringiensis HD1Mit9. The amino acids of $B$. subtilis (Bs) and B. thuringiensis (Bt) are numbered on the left side of the sequence. Identical residues are shown by a vertical line, and conserved substitutions are indicated by dots. One dot represents low similarity and two dots indicate high similarity between the two amino acids. 


\section{Growth Rate of HD1Mit9 and HD1Mit9::Tn917 \#1}

To determine whether the growth of HD1Mit9::Tn917 \#1 was impaired as a result of the transposon insertion, the growth rate of the sporulation mutant was compared to that of wild type HD1Mit9. The B. thuringiensis strains were grown in CYS medium. The growth rate of the cultures was monitored by OD600 for 11 hours until they reached the stationary phase (Figure 15). No obvious difference was seen between the growth rate of the wild type HD1Mit9 and HD1Mit9::Tn917 \#1. Both strains grew at the same rate and reached the stationary phase at approximately the same time. However, HD1Mit9::Tn917 \#1 entered logarithmic growth before the wild type strain. 


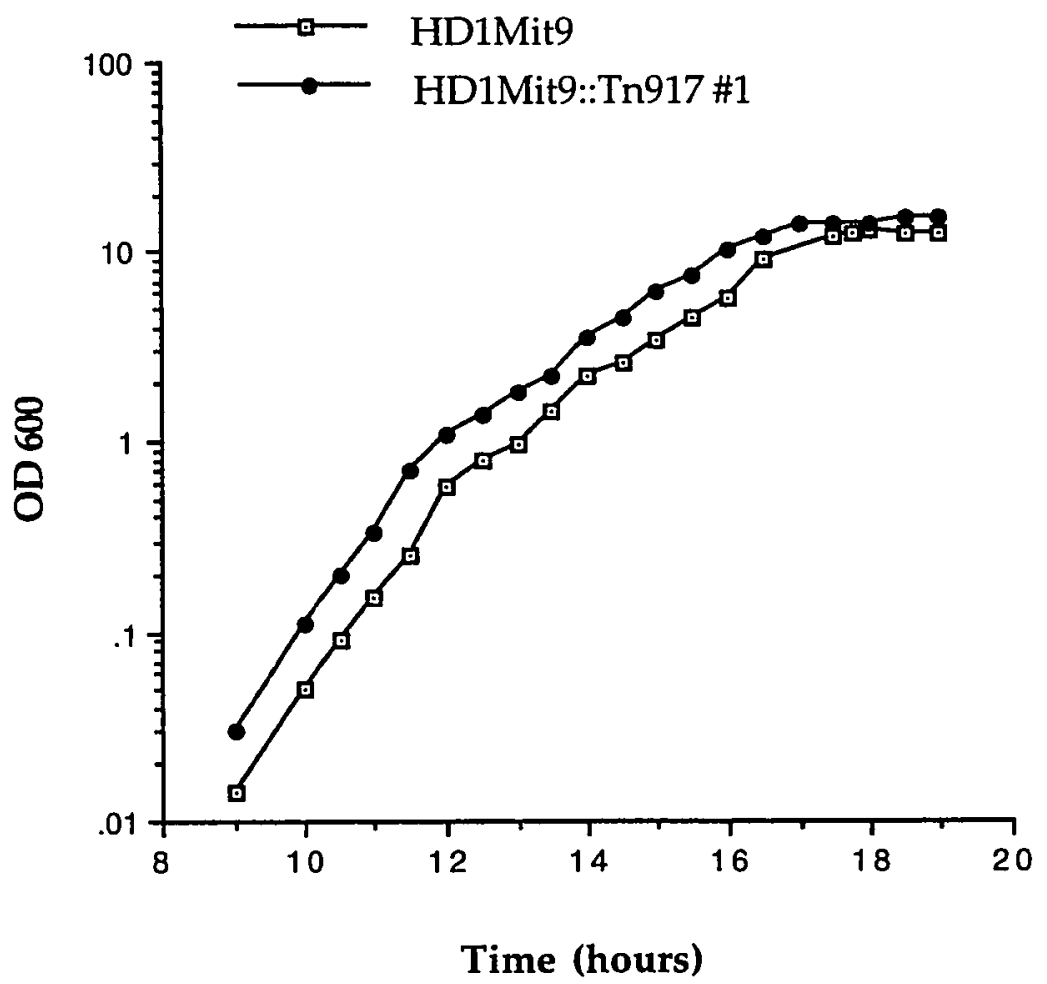

Figure 15. Growth curves of HD1Mit9 and HD1Mit9::Tn917 \#1. 


\section{Characterization of the Mutant Spores}

In the current study, the morphology of the spores produced by HD1Mit9::Tn917 \#1 was examined using a light microscope. The mutant spores were not fully developed (immature spores) and were darker (phase gray) than the wild type spores produced by strain HD1Mit9 (Figure 16). The immature spores were also slightly oval shaped as opposed to wild type spores that were more round.

According to Hill (1983), B. subtilis spoVJ mutants produce immature, phase gray spores that are sensitive to heat and organic solvents and resistant to lysozyme. In these experiments, the resistance properties of the mutant and the wild type spores against heat $\left(55^{\circ} \mathrm{C}\right.$ and $\left.65^{\circ} \mathrm{C}\right)$, lysozyme, and organic solvents (chloroform, acetone, toluene, 1-octanol) were compared (Table 5; Figure 17). The number of spores resistant to each treatment was obtained (Table 5). The percentage of resistant mutant spores was calculated by dividing the number of resistant mutant spores to the number of wild type spores (Table 5). The relative resistance of spores produced by strain HD1Mit9::Tn917 \#1, from the most resistant to the least resistant, were as follows: lysozyme, heat, toluene, chloroform, acetone, and 1-octanol. 


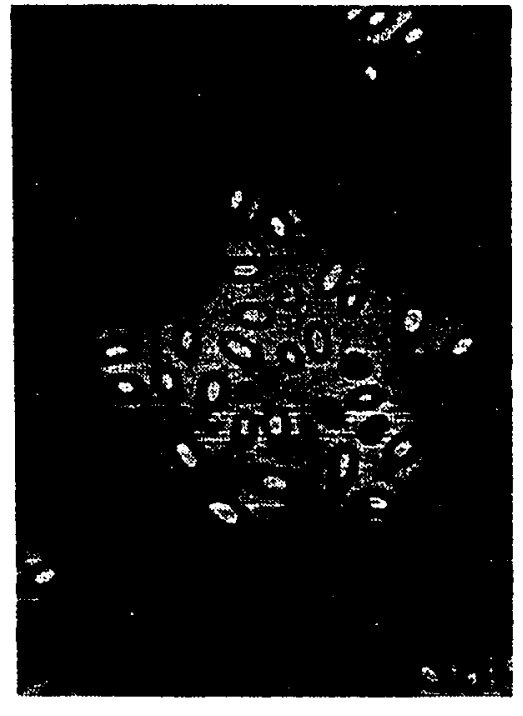

(a)

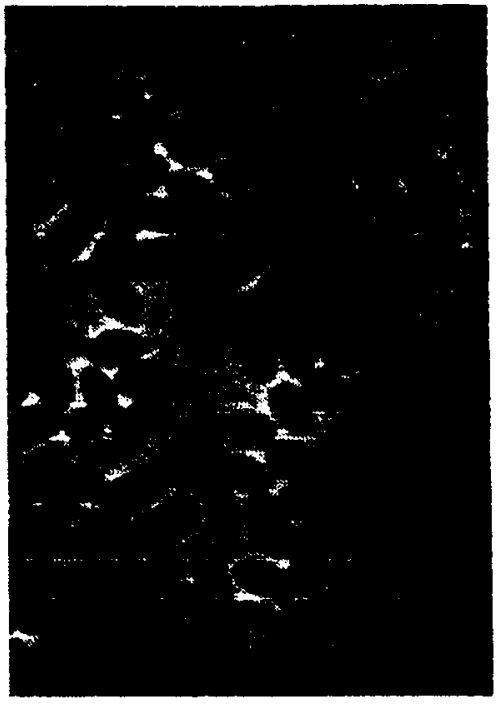

(b)

Figure 16. Spores from B. thuringiensis HD1Mit9 (a) and HD1Mit9::Tn917 isolate \#1 (b). 
Table 5. Resistance properties of HD1Mit9::Tn917 \#1 (mutant) and $B$. thuringiensis HD1Mit9 (wild type) spores to heat, lysozyme, and organic solvents

\begin{tabular}{llll}
\hline Treatment & $\begin{array}{l}\text { Wild type spores } \\
(\mathrm{CFU} / \mathrm{ml})\end{array}$ & $\begin{array}{l}\text { Mutant spores } \\
(\mathrm{CFU} / \mathrm{ml})\end{array}$ & $\begin{array}{l}\text { \% resistant } \\
\text { mutant spores }\end{array}$ \\
\hline $55^{\circ} \mathrm{C}$ & $3 \times 10^{8}$ & $1.6 \times 10^{3}$ & $5.3 \times 10^{-4}$ \\
$65^{\circ} \mathrm{C}$ & $3 \times 10^{8}$ & $2.3 \times 10^{3}$ & $7.7 \times 10^{-4}$ \\
Lysozyme & $3 \times 10^{8}$ & $3.15 \times 10^{7}$ & $1.05 \times 10$ \\
Acetone & $2 \times 10^{8}$ & $1 \times 10$ & $5 \times 10^{-6}$ \\
Chloroform & $2 \times 10^{8}$ & $5 \times 10$ & $2.5 \times 10^{-5}$ \\
$1-$ Octanol & $2.5 \times 10^{8}$ & 0 & 0 \\
Toluene & $2.4 \times 10^{8}$ & $1.2 \times 10^{2}$ & $5 \times 10^{-5}$ \\
\hline
\end{tabular}




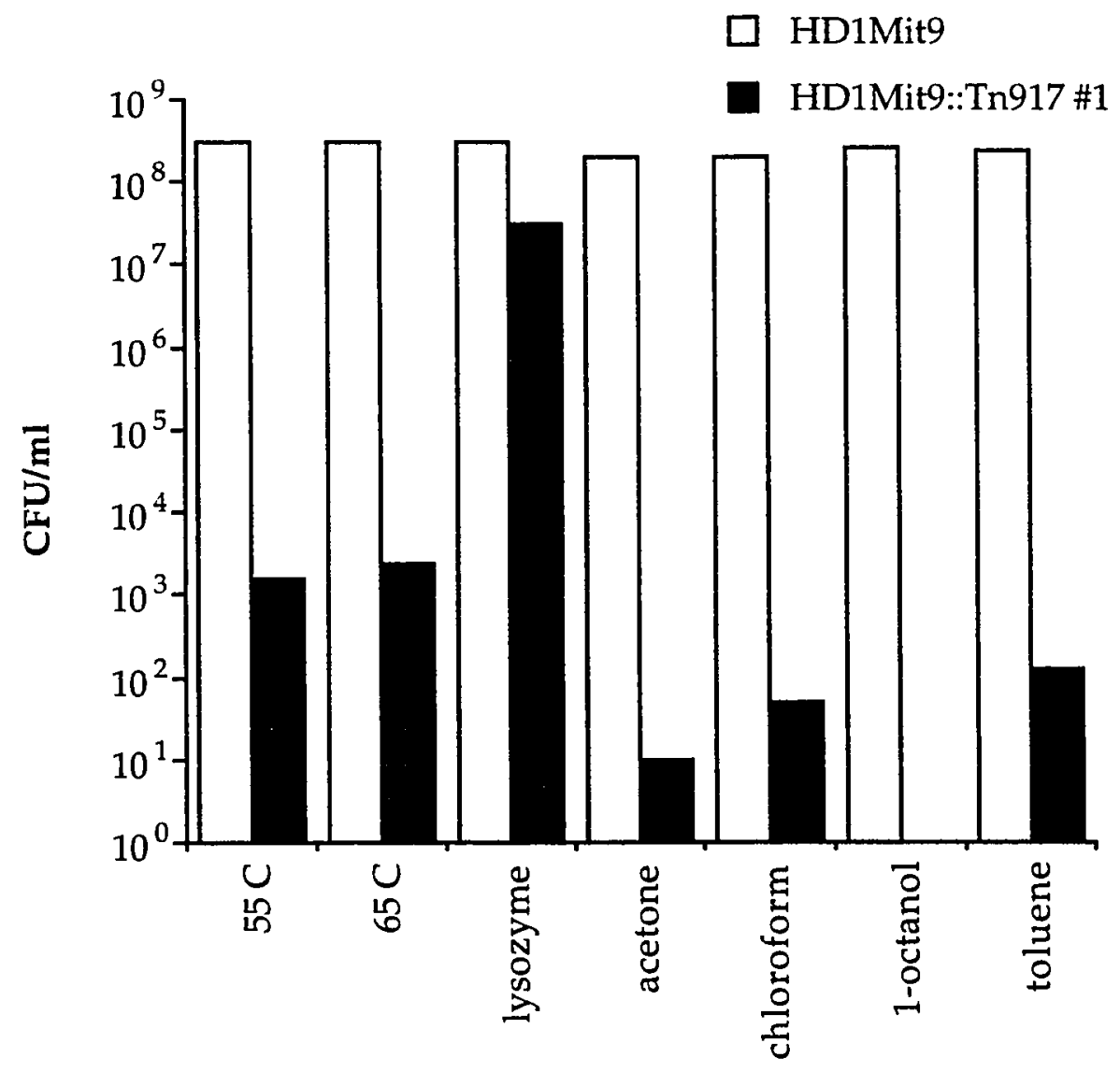

Figure 17. Resistance properties of spores from HD1Mit9 and HD1Mit9::Tn917 \#1 to heat, lysozyme, and organic solvents. 


\section{DISCUSSION}

Over the past 30 years, the physiological, morphological, and biochemical changes that are associated with sporulation have been studied in great detail in spore-forming bacteria such as B. subtilis (Errington, 1993). Some bacteria respond to poor nutritional conditions by forming a dormant cell type known as an endospore. Numerous studies have been done to identify and characterize the B. subtilis sporulation genes. B. subtilis does not contain naturally occurring plasmids, so the genes involved in sporulation are located on the chromosome. Also, it has been shown that the plasmidcured strains of $B$. thuringiensis, including HD1Mit9 which was used in this study, undergo normal sporulation. Although most $B$. thuringiensis strains carry a number of plasmids, it is assumed that the sporulation genes in this bacterium are also scattered on the chromosome. One of the most useful approaches for isolating sporulation genes is transposon-mediated insertional mutagenesis (Youngman, 1987). The transposon Tn91.7 has been used widely

for characterizing genes in B. subtilis (Sandman et al., 1987), B. megaterium (Tao and Vary, 1991), and L. monocytogenes (Camilli et al., 1990).

In the current study, a sporulation gene was identified in $B$. thuringiensis using Tn917 insertional mutagenesis. The method of mutagenesis used for $B$. thuringiensis was similar to the one used by Sandman et al. (1987) for B. subtilis with some modification. It was necessary to determine the best conditions to obtain efficient transposition in $B$. thuringiensis. Because of the inability of $B$. thuringiensis to grow at the high temperature used for B. subtilis transposition $\left(48^{\circ} \mathrm{C}\right)$, the $B$. thuringiensis cells 
were exposed to $39^{\circ} \mathrm{C}$ for a longer duration. This method proved effective for preparation of the $B$. thuringiensis insertion libraries. By increasing the number of times the culture was exposed to the high temperature, the plasmid pLTV1 became unstable and the transposition efficiency was increased. The B. subtilis culture was exposed to high temperatures two times as compared to three for the $B$. thuringiensis culture. When LB medium was used for transposition in B. thuringiensis, the number of transposed colonies obtained was extremely low (data not shown). Penassay broth was found to be more effective for the recovery of Tn917-insertions. However, the reason for its effectiveness is not understood. Penassay broth was also used successfully by Crawford and Streips (1990) for transposon $m$ : $\lambda$ tagenesis in $B$. thuringiensis.

Using transposon mutagenesis, a $B$. thuringiensis sporulation gene was identified and cloned in an E. coli strain. The gene was sequenced and compared to the $B$. subtilis sporulation genes. Approximately $70 \%$ identity at both the DNA and the protein level was observed between the $B$. thuringiensis sporulation gene and the spoVJ gene from B. subtilis.

Several other $B$. thuringiensis sporulation genes have been sequenced and compared to $B$. subtilis sporulation genes. The Spo0F proteins of $B$. thuringiensis and $B$. subtilis share $76 \%$ sequence identity (Malvar and Baum, 1994). The $B$. thuringiensis spo0A gene and its predicted product show a high degree of similarity to the $B$. subtilis spo0A gene and its protein product (Lereclus et al., 1995). The genes are $71 \%$ identical and the proteins $82 \%$ identical. Also, the amino acid sequences of the two RNA polymerase sigma factors, $\sigma^{35}$ and $\sigma^{28}$ from $B$. thuringiensis, have greater than $80 \%$ identity to 
the B. subtilis sporulation-specific $\sigma^{\mathrm{E}}$ and $\sigma^{\mathrm{K}}$, respectively (Adams et al., 1991). Based on these results, the percent identity between the $B$. thuringiensis and B. subtilis spoVJ genes was within a normal range.

Hill (1983) indicated that the B. subtilis spoVJ mutant was sensitive to organic solvents and heat but resistant to lysozyme. In the current study, the resistance properties of the $B$. thuringiensis sporulation mutant against heat, lysozyme, and several organic solvents were determined. The results indicated that the mutant spores from B. thuringiensis showed resistance to the lysozyme treatment. However, they were significantly sensitive to heat and chemicals such as acetone, chloroform, octanol, and toluene. These results were comparable to those obtained by Hill (1983). The B. thuringiensis sporulation mutant, like the B. subtilis spoVI mutant was oligosporogenous rather than asporogenous. It made approximately $10^{3}$ heat-resistant spores per $\mathrm{ml}$ of sporulated culture as opposed to $10^{8}$ spores per $\mathrm{ml}$ for wild type. This phenomenon has been observed in other stage $V$ mutations (Hill, 1983).

Based on the sequence comparison, it was believed that the $B$. thuringiensis sporulation gene was spoVJ. The spore-resistance experiments showed that the $B$. thuringiensis mutant had the same phenotype as the $B$. subtilis spoVJ mutant. Taken together, these results show that the isolated sporulation gene was indeed $B$. thuringiensis spoVJ.

The function of spoVJ in B. subtilis is not fully understood. According to Foulger and Errington (1991), the presence of a nucleotide-binding motif in the spoVI gene suggested that it required energy for its activity, or that it was regulated by a nucleotide. Also, Hill (1983) and Errington et al. (1988) have shown that the dipicolinic acid (DPA) produced by $B$. subtilis spoVJ mutants 
was not incorporated into the prespore, indicating that the SpoVJ protein might be involved in the DPA transport into the prespore.

Most strains of $B$. thuringiensis produce crystal proteins during sporulation which can be used for control of lepidopteran insects. Malvar and Baum (1994) as well as Lereclus et al. (1995) have shown that the expression of a particular crystal gene, cryIIIA, was increased in spoOF and spo0A mutants of $B$. thuringiensis. Because of this result, it is important to gain understanding of the genes regulating sporulation. These genes could be used to develop $B$. thuringiensis strains with high insecticidal activity for biological control of pest insects.

All commercial B. thuringiensis strains form spores which are released into the surroundings in combination with the insecticidal proteins. These spores are resistant and can survive in the soil under extreme weather conditions. Since $B$. thuringiensis is an ubiquitous, naturally occurring soil bacterium, the release of spores into the environment is not considered unsafe. In recent years, molecular biologists have been able to manipulate $B$. thuringiensis strains to increase potency against pest insects. Many of these recombinant strains contain antibiotic resistance genes used as selectable markers. As a result, some people are not supportive of the release of recombinant strains into the environment. By identifying sporulation genes, the spore-formation pathway in the recombinant $B$. thuringiensis strains can be manipulated to produce sporulation mutant strains that are not persistent in the environment. Thus, in terms of public acceptability, an asporogenic recombinant $B$. thuringiensis strain may represent an extremely attractive alternative to other genetically engineered strains. 


\section{LITERATURE CITED}

Adams, L. F., K. L. Brown, and H. R. Whiteley. 1991. Molecular cloning and characterization of two genes encoding sigma factors that direct transcription from a Bacillus thuringiensis crystal protein gene promoter. J. Bacteriol. 173:3846-3854.

Anagnostopoulos, C., and J. Spizizen. 1961. Requirements for transformation in Bacillus subtilis. J. Bacteriol. 81:741-746.

Beegle, C. C., and T. Yamamoto. 1992. Invitation paper (C. P. Alexander Fund): History of Bacillus thuringiensis Berliner research and development. Can. Ent. 124:587-616.

Bohall Jr., N. A., and P. S. Vary. 1986. Transposition of Tn917 in Bacillus megaterium. J. Bacteriol. 167:716-718.

Camilli, A., D. A. Portnoy, and P. Youngman. 1990. Insertional mutagenesis of Listeria monocytogenes with a novel Tn917 derivative that allows direct cloning of DNA flanking transposon insertions. J. Bacteriol. 172:3738-3744.

Cooper, D. 1994. Bacillus thuringiensis toxins and mode of action. Agric. Ecosystems Environ. 49:9-13.

Crawford, I. T., and U. N. Streips. 1990. Methods for mutagenesis of Bacillus thuringiensis. J. Microbiol. Methods 11:241-246.

de Barjac, H., and F. Lemille. 1970. Presence of flagellar antigenic subfactors in Serotype 3 of Bacillus thuringiensis. J. Invertebr. Pathol. 15:139-140.

Dulmage, H. T. 1970. Insecticidal activity of HD-1, a new isolate of Bacillus thuringiensis var. alesti. J. Invertebr. Pathol. 15:232-239.

Errington, J. 1993. Bacillus subtilis sporulation: regulation of gene expression and control of morphogenesis. Microbiol. Rev. 57:1-33.

Errington, J., S. M. Cutting, and J. Mandelstam. 1988. Branched pattern of regulatory interactions between late sporulation genes in Bacillus subtilis. J. Bacteriol. 170:796-801.

Foulger, D., and J. Errington. 1991. Sequential activation of dual promoters by different sigma factors maintains spoVJ expression during successive developmental stages of Bacillus subtilis. Mol. Microbiol. 5:1363-1373. 
Grindley, N. D. F., and R. R. Reed. 1985. Transpositional recombination in prokaryotes. Annu. Rev. Biochem. 54:863-896.

Hill, S. H. A. 1983. spoVH and spoVJ - new sporulation loci in Bacillus subtilis 168. J. Gen. Microbiol. 129:293-302.

Lereclus, D., H. Agaisse, M. Gominet, and J. Chaufaux. 1995. Overproduction of encapsulated insecticidal crystal proteins in a Bacillus thuringiensis spo0A mutant. Biotechnology 13:67-71.

Losick, R., P. Youngman, and P. J. Piggot. 1986. Genetics of endospore formation in Bacillus subtilis. Annu. Rev. Genet. 20:625-669.

Macaluso, A., and A. Mettus. 1991. Efficient transformation of Bacillus thuringiensis requires nonmethylated plasmid DNA. J. Bacteriol. 173:13531356.

Malvar, T., and J. A. Baum. 1994. Tn5401 disruption of the spo0F gene, identified by direct chromosomal sequencing, results in CryIIIA overproduction in Bacillus thuringiensis. J. Bacteriol. 176:4750-4753.

Milner, R. J. 1994. History of Bacillus thuringiensis. Agric. Ecosystems Environ. 49:9-13.

Moller, W., and R. Amons. 1985. Phosphate-binding sequences in nucleotide-binding proteins. FEBS Letts. 186:1-7.

Moran Jr., C. P., N. Lang, S. F. J. LeGrice, G. Lee, and M. Stephens. 1982. Nucleotide sequences that signal the initiation of transcription and translation in Bacillus subtilis. Mol. Gen. Genet. 186:339-346.

Perkins, J. B., and P. Youngman. 1986. Construction and properties of Tn917lac, a transposon derivative that mediates transcriptional gene fusion in Bacillus subtilis. Proc. Natl. Acad. Sci. USA 83:140-144.

Piggot, P. J., and J. G. Coote. 1976. Genetic aspects of bacterial endospore formation. Bacteriol. Rev. 40:908-962.

Sambrook, J., E. F. Fritsch, and T. Maniatis. 1989. Molecular Cloning: A Laboratory Manual, second edition. Cold Spring Harbor Laboratory, Cold Spring Harbor, N. Y. 
Sandman, K., R. Losick, and P. Youngman. 1987. Genetic analysis of Bacillus subtilis spo mutations generated by Tn917-mediated insertional mutagenesis. Genetics 117:603-617.

Shaw, J. H., and D. B. Clewell. 1985. Complete nucleotide sequence of macrolide-lincosamide-streptogramin B-resistance transposon $\operatorname{Tn} 917$ in Streptococcus faecalis. J. Bacteriol. 164:782-796.

Steinhaus, E. A. 1951. Possible use of Bacillus thuringiensis as an aid in the biological control of the alfalfa caterpillar. Hilgardia 20:359-381.

Tao, Y., and P. S. Vary. 1991. Isolation and characterization of sporulation lacZ fusion mutants of Bacillus megaterium. J. Gen. Microbiol. 137:797-806.

Thorne, C. B. 1968a. Transducing bacteriophage for Bacillus cereus. J. Virol. 2:657-662.

Thorne, C. B. 1968b. Transduction in Bacillus cereus and Bacillus anthracis. Bacteriol. Rev. 32:358-361.

Thorne, C. B. 1978. Transduction in Bacillus thuringiensis. Appl. and Environ. Microbiol. 35:1109-1115.

Tinoco, I., P. N. Borer, B. Dengler, M. D. Levine, O. C. Uhlenbeck, D. M. Crothers, and J. Gralla. 1973. Improved estimation of secondary structure in ribonucleic acids. Nature New Biol. 246:40-41.

Tomich, P. K., F. Y. An, and D. B. Clewell. 1980. Properties of erythromycininducible transposon Tn917 in Streptococcus faecalis. J. Bacteriol. 141:13661374.

Vandeyar, M. A., and S. A. Zahler. 1986. Chromosomal insertions of Tn917 in Bacillus subtilis. J. Bacteriol. 167:530-534.

Walker, J. E., M. Saraste, M. J. Runswick, and N. J. Gay. 1982. Distantly related sequences in the $\alpha$ - and $\beta$-subunits of ATP synthase, myosin, Kinases and other ATP-requiring enzymes and a common nucleotide binding fold. EMBO J. 1:945-951.

Watkinson, I. 1994. Global view of present and future markets for Bt products. Agric. Ecosystems Environ. 49:3-7. 
Whiteley, H. R., and H. E. Schnepf. 1986. The molecular biology of parasporal crystal body formation in Bacillus thuringiensis. Annu. Rev. Microbiol. 40:549-576.

Youngman, P. J. 1987. Plasmid vectors for recovering and exploiting Tn917 transposition in Bacillus and other gram-positive bacteria, p. 79-103. In K. Hardy (ed.), Plasmids: a Practical Approach. IRL Press, Oxford.

Youngman, P. J., J. B. Perkins, and R. Losick. 1983. Genetic transposition and insertional mutagenesis in Bacillus subtilis with Streptococcus faecalis transposon Tn917. Proc. Natl. Acad. Sci. USA 80:2305-2309. 